\title{
The role of cloud contamination, aerosol layer height and aerosol model in the assessment of the OMI near-UV retrievals over the ocean
}

\author{
Santiago Gassó ${ }^{1}$ and Omar Torres ${ }^{2}$ \\ ${ }^{1}$ Climate and Radiation Laboratory, NASA/GSFC, Code 613, Greenbelt, MD 20771, USA \\ ${ }^{2}$ Atmospheric Chemistry and Dynamics Laboratory, NASA/GSFC, Code 614, Greenbelt, \\ MD 20771, USA
}

Correspondence to: Santiago Gassó (santiago.gasso@nasa.gov)

Received: 6 January 2016 - Published in Atmos. Meas. Tech. Discuss.: 16 February 2016

Revised: 24 May 2016 - Accepted: 7 June 2016 - Published: 14 July 2016

\begin{abstract}
Retrievals of aerosol optical depth (AOD) at $388 \mathrm{~nm}$ over the ocean from the Ozone Monitoring Instrument (OMI) two-channel near-UV algorithm (OMAERUV) have been compared with independent AOD measurements. The analysis was carried out over the open ocean (OMI and MODerate-resolution Imaging Spectrometer (MODIS) AOD comparisons) and over coastal and island sites (OMI and AERONET, the AErosol RObotic NETwork). Additionally, a research version of the retrieval algorithm (using MODIS and CALIOP (Cloud-Aerosol Lidar with Orthogonal Polarization) information as constraints) was utilized to evaluate the sensitivity of the retrieval to different assumed aerosol properties.

Overall, the comparison resulted in differences (OMI minus independent measurements) within the expected levels of uncertainty for the OMI AOD retrievals $(0.1$ for AOD $<0.3$, $30 \%$ for AOD $>0.3$ ). Using examples from case studies with outliers, the reasons that led to the observed differences were examined with specific purpose to determine whether they are related to instrument limitations (i.e., pixel size, calibration) or algorithm assumptions (such as aerosol shape, aerosol height).

The analysis confirms that OMAERUV does an adequate job at rejecting cloudy scenes within the instrument's capabilities. There is a residual cloud contamination in OMI pixels with quality flag 0 (the best conditions for aerosol retrieval according to the algorithm), resulting in a bias towards high AODs in OMAERUV. This bias is more pronounced at low concentrations of absorbing aerosols (AOD
\end{abstract}

$388 \mathrm{~nm} \sim<0.5)$. For higher aerosol loadings, the bias remains within OMI's AOD uncertainties.

In pixels where OMAERUV assigned a dust aerosol model, a fraction of them $(<20 \%)$ had retrieved AODs significantly lower than AERONET and MODIS AODs. In a case study, a detailed examination of the aerosol height from CALIOP and the AODs from MODIS, along with sensitivity tests, was carried out by varying the different assumed parameters in the retrieval (imaginary index of refraction, size distribution, aerosol height, particle shape). It was found that the spherical shape assumption for dust in the current retrieval is the main cause of the underestimate. In addition, it is demonstrated in an example how an incorrect assumption of the aerosol height can lead to an underestimate. Nevertheless, this is not as significant as the effect of particle shape. These findings will be incorporated in a future version of the retrieval algorithm.

\section{Introduction}

Lack of information on absorbing aerosol properties (single scattering albedo, SSA, and aerosol absorption optical depth, AOD), as well as their horizontal and vertical distribution, have been singled out as one of the major sources of uncertainty in the computation of global radiative forcing (Loeb and Su, 2010; Bond et al., 2013, Gómez-Amo et al., 2014; Wang et al., 2014; Samset and Myhre, 2015). The satellite characterization of aerosol absorption contributes to the re- 
duction of this uncertainty by providing observational assessments to aid global climate models (Koch et al., 2009; Lacagnina et al., 2015). However, detection and characterization of aerosol absorption is difficult, and special requirements are needed in a satellite detector. For example, while it is possible to obtain SSA retrievals over bright surfaces using the MODerate-resolution Imaging Spectrometer (MODIS) (Kaufman, 1987; Zhu et al., 2011, Wells et al., 2012), these methods require elaborate analysis and aggregation of the data that render the method impractical for automation of the retrievals. Multi-angle measurements (Multi-angle Imaging SpectroRadiometer, MISR) allow for the qualitative identification of aerosol absorption (Kalashnikova and Kahn, 2008; Chen et al., 2008), but hardware limitations result in limited numbers of retrievals (Kahn and Gaitley, 2015). With a combination of polarization measurements along with multiple observing angles (POLDER instrument), it is possible to obtain SSA retrievals over the ocean (Hasekamp et al., 2011) and over clouds (Peers et al., 2015), but spatial resolution and viewing conditions are also limitations. The interaction of particle absorption and molecular scattering in the nearUV ( 330-400 nm) generates a unique spectral signal associated with the presence of UV-absorbing aerosols (primarily carbonaceous aerosol, desert dust and volcanic ash). At these wavelengths, molecular or Rayleigh scattering is the dominant signal in the upwelling radiation. When absorbing aerosols are present, they absorb some of the molecular scattered radiation. At these wavelengths, the measured spectral dependence in the presence of aerosol absorption is different than the well-known spectral dependence of Rayleigh scattering, and this signal can be used to derive aerosol properties (Torres et al., 1998; Veihelmann et al., 2007). With the appropriate selection of a pair of near-UV wavelengths where gas absorption is negligible, this aerosol absorption signal can be interpreted via an inversion algorithm (Torres et al., 1998, 2005), yielding SSA values comparable to those from ground-based observations (Torres et al., 2005, 2007; Jethva et al., 2014).

The Ozone Monitoring Instrument (OMI), deployed in 2004 on board the Aura satellite (Levelt et al., 2006) is a hyperspectral sensor covering the wavelength range 270 to $500 \mathrm{~nm}$. Although its primary application is the retrieval of trace gases, observations in the near-UV are used for the retrieval of AOD and SSA (Torres et al., 2007). These products are part of the standard operational suite of OMI products. There are two sets of such products following very different approaches. A KNMI-Dutch aerosol retrieval approach (labeled OMAERO, Curier et al., 2008) uses a multiplewavelength algorithm and the NASA-US retrieval algorithm, following the retrieval approach used in the TOMS detectors (labeled OMAERUV, Torres et al., 2007). The analysis shown in this study concerns only the retrievals of the OMAERUV algorithm. Because trace-gas retrieval sensors require a very high signal-to-noise ratio and, therefore, coarse spatial resolution, its native pixel size is not well suited for aerosol retrievals. Pixels at nadir have a ground size of $24 \times 13 \mathrm{~km}^{2}$, whereas at the edge of the scan the detector's elements can be well over $100 \mathrm{~km}$ wide.

Comparisons of the OMAERUV retrievals of the AOD and SSA with independent measurements have been made over land sites (Torres et al., 2007, 2013; Ahn et al., 2008, 2014; Jethva et al., 2014), and a number of features have been identified that impact the retrieval, mainly the height of the aerosol layer under observation and subpixel cloud contamination. Among these, cloud contamination has been identified as the largest source of error in the UV irradiance and clear sky aerosol retrievals by our group and others (Kazadzis et al., 2009). However, the extent and quantification of the impact introduced by the presence of undetected clouds in the pixel has not been established. The validation of aerosol retrievals over land has been the focus of a number of OMI comparison studies (Ahn et al., 2014; Jethva et al., 2014; Zhang et al., 2015) with AERONET (the AErosol RObotic NETwork, Holben et al., 1998), but there are no specific studies dedicated to OMI retrievals over the ocean.

There are four objectives in this paper: (1) to assess the OMAERUV AOD retrievals over the ocean; (2) to establish and if possible, estimate the impact of cloud contamination in the AOD retrievals; (3) to demonstrate with specific examples the impact of aerosol concentration and height in the OMAERUV retrievals; (4) and to determine conditions that lead to discrepancies between OMI retrievals and independent measurements. This better understanding of the OMAERUV retrievals will result in improvements not only in AOD, but also in aerosol absorption and aerosol type identification.

The motivation for examining retrievals over the ocean is twofold. An examination of the impact of cloud contamination in the retrievals will be important in applications such as transport of dust and pollution across the Atlantic and Pacific basins. This requires an adequate characterization of OMI aerosol optical depth retrievals over the ocean. The other reason is methodological. In order to evaluate the OMI AOD retrievals at $388 \mathrm{~nm}$ away from AERONET sites, the MODIS visible AOD will be extrapolated to the UV using the method of Satheesh et al. (2009), and this method is only applicable over the ocean.

This paper is structured as follows. Section 2 gives details of sources of data, assumptions and approaches used to compare OMI, MODIS, CALIOP (Cloud-Aerosol Lidar with Orthogonal Polarization, Winker et al., 2003) and AERONET retrievals. In addition, brief descriptions of the OMAERUV operational (Torres et al., 2013) and hybrid (Satheesh et al., 2009) algorithms are provided. Then, a comparison and statistics of AOD retrievals over coastal and island AERONET sites is shown (Sect. 3). This analysis is expanded by inspecting case studies in detail using collocated MODIS observations and it characterizes the impact of cloud contamination (Sect. 4). Selected cases of elevated smoke and dust layers are studied using MODIS and CALIOP data 
to illustrate in detail how aerosol height and concentration impact the AOD retrieval (Sect. 5). Section 6 discusses radiative transfer calculations carried out to determine whether the aerosol model assumption used in OMAERUV accounts for most of the differences between observation and model in the AOD retrieval. Section 7 summarizes the results and the recommendations to the users.

\section{Methods}

\subsection{Ozone Monitoring Instrument (OMI)}

\subsubsection{Description of OMI}

The Aura-OMI mission is an international scientific partnership involving the United States, the Netherlands and Finland (Schoeberl et al., 2006). By incorporating hyperspectral capabilities (channels with $0.5 \mathrm{~nm}$ width in the $270-500 \mathrm{~nm}$ range, Levelt et al., 2006), OMI is an improved successor of a number of sensors (the Total Ozone Mapper Spectrometer, the Global Ozone Monitoring Experiment and the Scanning Imaging Absorption Spectrometer for Atmospheric Chartography) used for the monitoring of ozone and other trace gases. With a nadir spatial resolution of $13 \times 24 \mathrm{~km}^{2}$ (higher than its predecessors), along with a $\sim 2600 \mathrm{~km}$ swath, OMI observed the whole globe with daily frequency during the first 4 years of operation, and about every 2 days since late 2008. Since its deployment in 2004 until at least the writing of this report (2016), OMI has remained operational and has contributed data on important subjects such as detection and transport of air pollution (Marmer et al., 2009; Zhao and Wang, 2009; Duncan et al., 2014; Chin et a, 2014), ozone studies (Ziemke et al., 2014), and volcanic monitoring (Carn et al., 2008; Krotkov et al., 2010; Wang et al., 2013), retrieval of aerosol optical depth and single scattering albedo in cloudfree scenes (Torres et al., 2007; Curier et al., 2008, Ahn et al; 2014; Jethva et al., 2014), the simultaneous retrieval of cloud and aerosol optical depth when aerosol layers are observed above cloud decks (Torres et al., 2012), aerosol model evaluation (Buchard et al., 2015; Zhang et al., 2015), trace gases and biomass burning (Castellanos et al., 2015) and organic aerosol analysis (Hammer et al., 2016). Notably, the instrument's calibration has remained remarkably stable (Ahn et al., 2014).

Each cross-track OMI swath consists of 60 pixels, also referred to as rows. Since June 2007, a detector anomaly has appeared and it affects the quality of the level $1 \mathrm{~B}$ radiance data at all wavelengths of OMI. Since it impacts consecutive rows in the detector, it is termed "Row Anomaly". This anomaly is dynamic and the number of impacted rows changes over time, resulting in a variable number of pixels unsuitable for retrievals. In practical terms, starting in mid2007 , between 5 and $50 \%$ of the pixels in each OMI orbit cannot be used for Level 2 inversions, and global coverage is now achieved every 2 days. The OMI Science team created screening algorithms to detect radiances impacted by the Row Anomaly. More details and updates on the status of the anomaly can be found at http://www.knmi.nl/omi/research/ product/rowanomaly-background.php.

The work described here makes use of the data produced at native spatial resolution (Level 2 OMAERUV, version 1.4.2, and the data record is available from http://disc.sci.gsfc.nasa. gov/Aura/data-holdings/OMI/omaeruv_v003.shtml). The general algorithm is described in Torres et al. (2007), and the latest algorithmic upgrades are documented in Torres et al. (2013).

\subsubsection{Aerosol data from the OMI near-UV algorithm (OMAERUV)}

The main aerosol products from the OMAERUV algorithm are the single scattering albedo (SSA) and the aerosol optical depth (AOD) at $388 \mathrm{~nm}$. Two essential parameters used in the retrieval are the $388 \mathrm{~nm}$ Lambert Equivalent Reflectance (LER) and the Absorbing Aerosol Index (AAI), as described in Torres et al. (2007).

The OMAERUV algorithm (version 1.4.2) assumes a set of absorbing (labeled smoke and dust) and non-absorbing (pollution or sulfate) aerosol types (Table 1). Each aerosol type is characterized by a fixed bimodal spherical particle size distribution with parameters derived from long-term AERONET statistics (Dubovik et al., 2002). The relative spectral dependence of the imaginary component of refractive in the $354-388 \mathrm{~nm}$ range is assumed for each aerosol type (Torres et al., 2007), and has been recently modified for the smoke type to account for the absorption effects of organic carbon (Jethva and Torres, 2011). Additional descriptions and details of ancillary data used can be found in Torres et al. (2013).

OMAERUV is structured internally as two different retrieval schemes depending on whether the pixel has been identified as an "ocean" or "land" pixel according to the ancillary surface type database (Torres et al., 2013). The ocean algorithm retrieves AOD and SSA only when both the AAI value is larger than a threshold (currently set at 0.8 ) and the aerosol type is determined be either carbonaceous or desert dust. The ocean's surface can bias the aerosol retrieval when phytoplankton blooms and/or surface roughness are not accounted for. The algorithm minimizes the impacts of these effects by selecting pixels with a high AI threshold since ocean blooms tend to have a positive AI but usually no larger than 0.5. Surface angular dependencies are most predominant near the sun glint areas and they are partially avoided by excluding these areas based on viewing geometry considerations. Thus, background non-absorbing aerosols (i.e., low AI aerosol) over the oceans are not retrieved because of the difficulties in separating the background aerosol signal from ocean color effects. In contrast, all three aerosol types are used over land (the retrieval scheme is detailed in Tor- 
Table 1. Number particle size bi-lognormal distribution parameters and real refractive index for the aerosol types (sulfate is denoted by SLF, biomass burning by SMK) assumed in the OMI near-UV algorithm. Number particle size distribution parameters: fine- and coarse-mode radii $(\mathrm{R} 1,2)$ and variance $(\mathrm{S} 1,2)$, coarse-mode fraction. The bottom table list nodal points in imaginary refractive index (wavelength-independent for the sulfate and spectrally dependent for smoke and desert dust aerosols) (adapted from Torres et al., 2007; Jethva and Torres, 2011).

\begin{tabular}{lllllll}
\hline Model & R1 & R2 & S1 & S2 & Fraction & Real \\
\hline SLF 1-7 & 0.088 & 0.509 & 1.499 & 2.16 & 0.0004 & 1.40 \\
SMK 1-3 & 0.087 & 0.567 & 1.537 & 2.203 & 0.0002 & 1.50 \\
SMK 4-7 & 0.080 & 0.705 & 1.492 & 2.075 & 0.0002 & 1.50 \\
DST 1-7 & 0.052 & 0.670 & 1.697 & 1.806 & 0.0044 & 1.55
\end{tabular}

\begin{tabular}{ll}
\hline Model & Imaginary $354 / 388 \mathrm{~nm}$ \\
\hline SULF & $0.0,0.002,0.004,0.006,0.008,0.01,0.12$ \\
SMK & $0.0 / 0.0,0.006 / 0.005,0.012 / 0.01,0.024 / 0.02,0.036 / 0.03,0.048 / 0.040,0.0576 / 0.0480$ \\
DUST & $0.0 / 0.0,0.0013 / 0.0001,0.0026 / 0.0018,0.0056 / 0.0040,0.0083 / 0.0060,0.0130 / 0.0092,0.023 / 0.017$ \\
\hline
\end{tabular}

res et al., 2013). It is important to reiterate one aspect of the retrieval here . Because the near-UV retrieval of absorbing aerosol properties is sensitive to layer height, a set of five pairs of AOD and SSA are pre-computed at five assumed aerosol heights $(0,1.5,3.0,6.0$ and $10 \mathrm{~km})$ for the viewing geometry of the pixel. The final retrieved AOD and SSA at $388 \mathrm{~nm}$ are obtained by interpolating in height using the aerosol height $\left(Z_{\mathrm{c}-\mathrm{clm}}\right)$ given by the CALIOP-based climatology (Chen et al., 2012). The five sets of pairs of AOD and SSA along with the interpolated final values corresponding to the $Z_{\mathrm{c}-\mathrm{clm}}$ are included in the OMAERUV file. The retrieved aerosol parameters are converted to 354 and $500 \mathrm{~nm}$ using the spectral dependence associated with the selected aerosol type.

\subsection{MODIS Level 2 data over the ocean}

In this analysis, MODIS Level 2 data (collection 5.1) generated by the ocean algorithm (Remer et al., 2005; Levy et al., 2009) are used. Only the features of the algorithm relevant to this analysis are highlighted here.

Over the ocean, the surface can be assumed as dark and fairly constant (except for variations dependent on surface wind speed). MODIS AOD retrievals are carried out using seven bands $(0.47,0.55,0.66,0.86,1.24,1.63$ and $2.13 \mu \mathrm{m})$. The ocean products have been compared against independent datasets (Zhang and Reid, 2010; Kittaka et al., 2011; Shi et al., 2011), and some deficiencies have been noted, such as biases due to variable surface reflectance with wind speed, cloud contamination, poor coverage at high latitudes and angular and calibration biases.

The MODIS Level 2 data are reported at spatial resolution of $10 \times 10 \mathrm{~km}^{2}$ (nadir), representing an analysis of 400 half-kilometer pixels inside. The number of pixels that did not pass a series of cloud tests inside the $10 \times 10 \mathrm{~km}^{2}$ box is reported in the variable named Cloud_Fraction_Ocean in the respective MODIS file, and this product is used in the comparisons with $\mathrm{OMI}$ in the next sections (it will be referred to as $\mathrm{CF}$ ). The MODIS CF is not quite comparable to the OMI cloud detection scheme because the latter is a threshold test, whereas MODIS CF is a combination of several tests.

A significant part of this analysis was carried out when the MODIS collection 5.1 was available. At the time of this submission a new MODIS version had already been released (collection 6). This version results in a slight decrease (in average) with respect to collection 5.1 over the ocean (AODs are $\sim 0.04$ lower). Specifically the difference is most notable at high latitudes and midlatitudes (poleward of $40^{\circ}$ latitude, Levy et al., 2013). It is expected that the differences between C6 and C5.1 MODIS AOD products are minimal for the application presented here since all collocations with OMI using MODIS are located within $30^{\circ}$ from the equator.

\subsection{The OMI-MODIS hybrid method}

In order to quantitatively compare OMI AODs over areas away from AERONET sites, the parameterizations developed by Satheesh et al. (2009) are used to obtain a MODIS AOD extrapolated to $388 \mathrm{~nm}$. The parameterization linearly extrapolates the MODIS AOD from 470 to $388 \mathrm{~nm}$ and then it applies a correction dependent on the MODIS finemode fraction product (only available over the ocean). This MODIS-based AOD 388 was used by Satheesh et al. (2009) as input in a combined MODIS-OMI research algorithm to derive aerosol height and SSA at $388 \mathrm{~nm}$. The method relies on the existing information available in OMAERUV's level 2 product. Figure 1 illustrates the derivation procedure in OMAERUV and the Satheesh et al. (2009) method. In the latter, the extrapolated MODIS AOD ( $\tau_{\mathrm{MOD}}$ in Fig. 1) is used in conjunction with the set of retrieved values of AODs and SSAs for the five assumed heights available in each pixel (Sect. 2.1). The MODIS-extrapolated AOD is an entry point in this table (black thick arrow in Fig. 1), and the corresponding values of aerosol height and SSA are found by interpolation. The same figure illustrates how OMAERUV chooses a final pair of AOD and SSA by using the clima- 


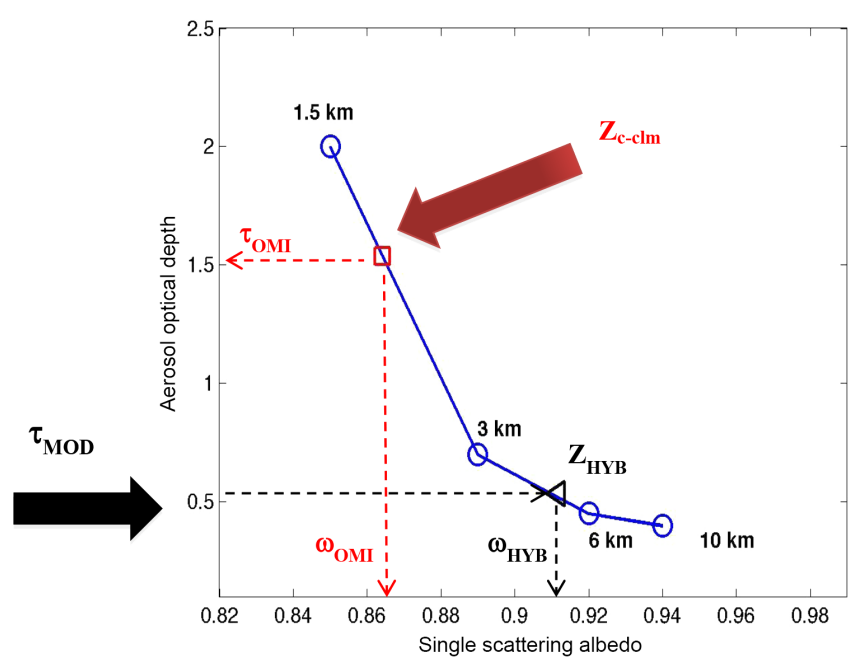

Figure 1. Illustration of the standard (or operational) and hybrid (Satheesh et al., 2009) retrieval schemes. The OMAERUV algorithm computes the pair of AOD and SSA at four assumed aerosol heights for the pixel's viewing geometry (blue solid lines and circles). In a prior step, it selected an aerosol model and surface albedo used in the computation. Each triplet (height, SSA and AOD) has a corresponding upwelling radiance matching the observed radiance by OMI. To select the final (or retrieved) aerosol height and SSA for the pixel, the standard (OMAERUV) algorithm uses a climatological height $\left(Z_{\mathrm{c}-\mathrm{clm}}\right)$ to determine the final AOD and SSA (red arrow and red dashed lines). The hybrid method uses a MODIS AOD (extrapolated to $388 \mathrm{~nm}$ ) as the entry point (black arrow and black dashed lines) to determine the $Z$ and SSA using the triplets from the lookup table.

tological value of the aerosol height $\left(Z_{\mathrm{c}-\mathrm{clm}}\right)$ as the best guess of the aerosol height in the pixel (entry point is the red arrow). Satheesh et al. (2009) compared the retrieved aerosol height with surface-based lidar and obtained a very good agreement. This method works best when the extrapolated MODIS AOD falls between the AOD values included in the OMI LUT. When this is not the case (for example when MODIS assumes a spectral dependence of an aerosol type different than the aerosol type detected by OMAERUV), the retrieved aerosol height can be unrealistically high or low due the non-linear of the curve (Fig. 1).

When comparing with OMI standard or operational retrievals, the MODIS-based AOD 388, height and SSA derived by the Satheesh et al. (2009) method will be referred to as the hybrid or extrapolated AOD, hybrid height $\left(Z_{\mathrm{hyb}}\right)$ and hybrid SSA throughout this paper.

A clarification about Fig. 1 is in order. It only shows four nodes at different heights despite that the LUT contains five nodes of each height. It became clear in the course of this analysis that the current assumed aerosol height $(0 \mathrm{~km})$ for the fifth node yields hybrid heights and SSAs not consistent with retrievals using the other four nodes. Thus, when the resulting hybrid height is lower than $1.5 \mathrm{~km}$, the final $Z_{\mathrm{hyb}}$ is derived by extrapolating from the closest node point (in this case, $1.5 \mathrm{~km}$ ). This fifth node was removed from the figure for clarity and in the next version of the algorithm the aerosol height associated for this node will be re-evaluated.

\subsection{CALIPSO data}

CALIOP is a lidar on board the CALIPSO platform flying in formation along with the Aqua and Aura satellites. It measures the attenuated backscatter at 532 and $1064 \mathrm{~nm}$. CALIOP probes the atmosphere between the surface and $40 \mathrm{~km}$ above sea level at a vertical resolution that varies between 30 and $60 \mathrm{~m}$. The horizontal resolution along the orbital track is $333 \mathrm{~m}$ (Winker et al., 2003). The CALIPSO satellite was launched on 28 April 2006 in an ascending polar orbit with a 13:32 (local) equator crossing time. In this work we use the $1064 \mathrm{~nm}$ daytime Level 1 attenuated backscatter product to determine the location and thickness of the aerosol layer under observation. Although there is a $532 \mathrm{~nm}$ channel available in the same platform, recent studies suggest that this channel tends to saturate at high aerosol loadings (Liu et al., 2011). In many instances, the full extent of carbonaceous aerosol layers in the column is not detected by the laser due to strong attenuation of the signal due to aerosol absorption effects (Torres et al., 2013). Because the case studies shown here contain absorbing aerosols at high concentrations, the $1064 \mathrm{~nm}$ data are favored.

In this work, CALIOP profiles are used to verify the location of the aerosol layer in the atmospheric column and compare with the layer height assumed by the OMAERUV algorithm. For the specific events analyzed in this work, the CALIOP aerosol layer altitude is determined as the mean aerosol layer height weighted by the attenuated backscattering coefficient at $1064 \mathrm{~nm}$ (Torres et al., 2013). The derived mean height from the CALIOP profile for a specific pixel is labeled $Z_{\mathrm{c}-\text { inst }}$.

\subsection{AERONET data over the ocean}

The AERONET (AErosol RObotic NETwork) program (Holben et al., 1998) is a network of automatic robotic Sun- and sky-scanning radiometers measuring and retrieving aerosol characteristics around the world. AERONET uses directSun radiance measurements at a 15 min interval to measure aerosol optical depths at 340, 380, 440, 500, 670, 870 and $1020 \mathrm{~nm}$ at most sites. The measurements are carried out during daylight hours. In this study, AERONET AODs at $380 \mathrm{~nm}$ were compared with the simultaneous corresponding retrieval from OMI. Note the AERONET reports AODs at $380 \mathrm{~nm}$, whereas OMI AODs are reported at $388 \mathrm{~nm}$, and this small wavelength difference is ignored in the comparisons shown here. 


\subsection{Considerations when overlapping MODIS and OMI aerosol products}

A number of factors need to be considered in overlapping MODIS and OMI Level 2 data. First, the detectors do not see the same air mass at the same time. Aura trailed Aqua by 15 min since its deployment until 2008 when it was brought closer to Aqua and the time difference was shortened to about $8 \mathrm{~min}$. The initial time difference of $15 \mathrm{~min}$ is probably more problematic since in such a time period, for example, a fair weather cumulus cloud could change its albedo considerably or a new cloud could form, as it is the case over the tropical oceans. A 7-8 min difference is in the upper end of acceptable time difference for using a high spatial resolution instrument collocated with a coarser resolution instrument (Genkova et al., 2012). Thus, this consideration has to be kept in mind when comparing data from both instruments on the same pixel. For simplicity, the overlap procedure implemented makes no correction for this time difference and it assumes that the aerosol optical properties remain the same between the two overpasses. The case studies reported here were specifically chosen because the minimal time difference between Aqua and Aura overpasses.

Second, when overlapping an OMI native-resolution pixel $\left(13 \times 24 \mathrm{~km}^{2}\right.$ nadir $)$ with the MODIS multi-pixel aggregate aerosol product $\left(10 \times 10 \mathrm{~km}^{2}\right.$ nadir $)$, a decision must be made regarding whether to use a single MODIS retrieval (for example, the closest) or all those MODIS retrievals that fall inside the OMI pixel and weight their contribution in some way (such as by the area overlapping with the OMI pixel). While the latter seemed more rigorous and representative, our tests indicated that such an operation required a number of assumptions that did not seem practical for this application. For example, when applying a weight by area, those MODIS $10 \times 10 \mathrm{~km}^{2}$ pixels partially overlapping the OMI pixel would have a different contribution depending on the time difference between the two detectors. Additionally, the MODIS $10 \times 10 \mathrm{~km}^{2}$ product is in fact the result of the aggregation of several $500 \mathrm{~m}$ native pixels, and the distribution of cloudy pixels is unknown within the $10 \times 10 \mathrm{~km}^{2}$ pixel aggregate. Thus, the criterion adopted here is based on choosing the closest MODIS AOD retrieval to the OMI pixel center and store all the relevant MODIS and OMI aerosol information.

Both detectors are approximately aligned, and tend to have similar viewing geometries. However, while both eastern edges of the respective swaths align well, the western edges do not because the detectors do not have the same swath (MODIS swath is approximately $2300 \mathrm{~km}$, whereas in OMI, the swath is about $2600 \mathrm{~km}$ ). Consequently, OMI's first few rows (typically rows 1 to 4 ) cannot be used in a collocation with MODIS. The eastern edge rows, however, are included in this analysis.

Typically, about four MODIS $10 \times 10 \mathrm{~km}^{2}$ pixels overlap an OMI pixel near the nadir and not necessarily, a single full
MODIS pixel is contained in it. At the edges of the OMI swath, the number increases to about 6 to 8 pixels due to the longitudinal stretching and 1 or more MODIS pixels are fully contained within the OMI pixel.

The joint OMI-MODIS analysis was carried out by overlapping data from each satellite's orbit. For each OMI orbit, each pixel with a successful AOD retrieval was collocated with the closest MODIS pixel with a successful AOD retrieval. Starting in 2008 the Row Anomaly in OMI began to expand eastward, reducing the number of functional pixel elements. Thus, as a result of the combined effect of glint masking, differences in swath coverage by the two sensors and OMI Row Anomaly, only about one-third of the pixels in the overlapping orbits are suitable for comparison.

In this analysis, it is assumed that the MODIS retrieval is closer (compared to the OMI retrieval) to the actual value since MODIS AODs have been fairly well characterized over the ocean (Smirnov et al., 2009; Kleidman et al., 2011; Shi et al., 2011).

\section{AERONET and OMI AOD comparisons}

A total of 20 sites located at islands and 13 located at the coasts of large continental masses (Table A1) were selected for collocation with the OMI overpasses. The selection criterion was based on whether the observations were available for an extended period and availability of a $380 \mathrm{~nm}$ channel at the site.

The collocation scheme was based on the following criteria: only AERONET Level 2 data were used, observations were averaged over a time window of 20 min centered at the time of the satellite overpass, the distance from the AERONET site to the center of the OMI was less than $40 \mathrm{~km}$, the OMI retrieval had to have a quality flag 0 (i.e., probably clear sky according to OMAERUV) for the selected pixel. In addition and in order to ensure that only AODs from the ocean algorithm are compared with AERONET, only pixels fully containing an ocean surface (as identified by OMAERUV internal topography database) are used in the comparison. This is different than in Ahn et al. (2013), where in coastal sites, the AODs were averaged over land and ocean pixels within the selected radius. Our approach results in a reduction of all the potential pixels available at coastal sites but it is compensated by considering a longer time period (than in Ahn et al., 2013).

Figure $2 \mathrm{a}$ and $\mathrm{b}$ show scatter plots of AOD $380 \mathrm{~nm}$ OMI vs. AERONET for the period September 2004December 2013 for all coastal and island sites. Each point is colored by the number of successful OMI AOD retrievals surrounding the selected pixel $\left(N_{\mathrm{OMI}}\right)$. This coloring provides an indirect assessment of the cloudiness of the surrounding area. The OMAERUV algorithm tests the magnitude of the LER in the pixel. If it is too high $(>0.3)$, it is deemed too bright for a clear sky retrieval (presumably be- 

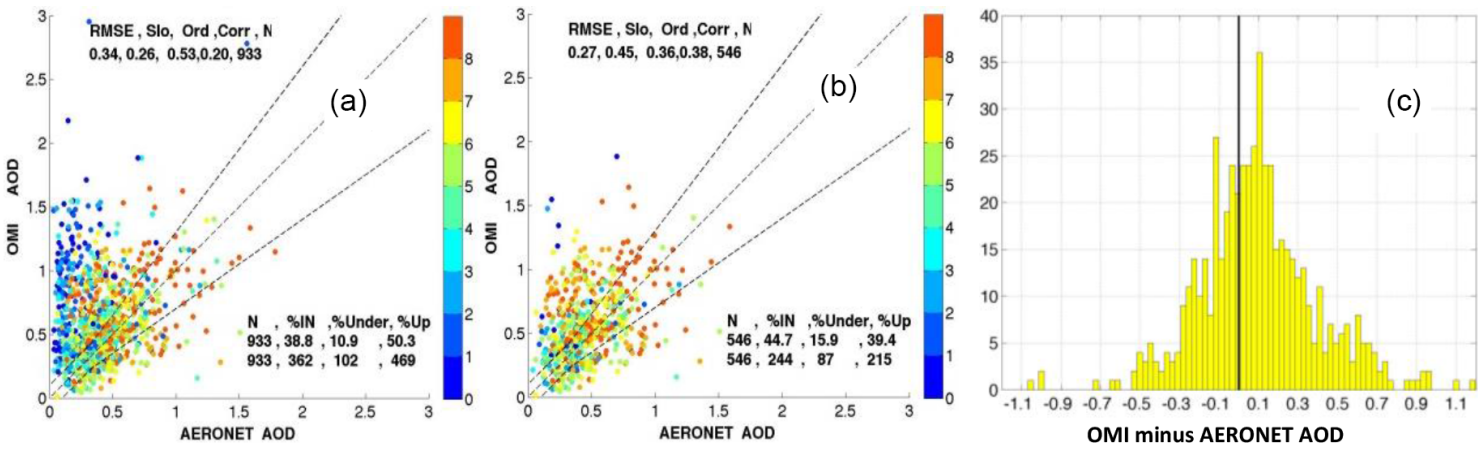

Figure 2. Collocated comparison of OMI AOD $388 \mathrm{~nm}$ with AERONET AOD $380 \mathrm{~nm}$ for absorbing aerosols (dust/smoke) as identified by OMAERUV over the ocean. Color bar indicates the number of successful OMI retrievals (out of a possible eight) around the selected OMI pixel used to compare with AERONET. AERONET sites are located along continental coastlines and islands. (a) All AERONET coastal and islands sites. (b) Comparison only for coastal. Root mean square error (RMSE), slope, ordinate, correlation coefficient and number of points used are shown in the upper left. The percentage and actual number of points above, inside and below of the uncertainty envelope are displayed in the bottom right of each figure. The black dashed lines are the 1-to- 1 line and the uncertainty envelope (defined as 0.1 for AOD $<0.3$ and $30 \%$ for AOD $>0.3$, Torres et al., 2007). (c) The histogram of OMI minus AERONET AODs for (b).

cause clouds) and no retrieval is carried out. Thus, out of the 8 surrounding pixels, low values of $N_{\mathrm{OMI}}$ are probably due to the presence of clouds around the selected OMI pixel. While $N_{\text {OMI }}$ can be low for other reasons (such as fresh snow on the ground), it provides an additional measure of the homogeneity of the radiance field A (and presumably of cloud fields) around the site.

Figure 2a shows that a significant number of pixels with overestimated OMI AOD are surrounded by low $N_{\text {OMI }}$. Figure $2 \mathrm{~b}$ show the same comparison but only for coastal sites. The contrast between figures suggests that coastal sites have fewer OMI overestimates at low AERONET AODs and those pixels are surrounded by higher $N_{\mathrm{OMI}}$ than in the island sites. Coastal sites are more influenced by dry air masses originating from the continent (for example, Dakar, Dhadnah). As a result, cloud occurrence in the OMI pixel is less frequent at these sites. Island sites far away from the continents are more influenced by humid marine air masses and likely to have surrounding clouds (e.g. eastern North Atlantic sites like Puerto Rico or Bermuda). Island sites within a few hundred kilometers of the continent may exhibit both regimes depending on the air mass, for example the Tenerife and Cabo Verde sites frequently exhibit clear sky conditions similar to those observed upwind in Dakar because the same dry air mass covers all these sites. Still, OMI AODs tend to be overestimated over coastal sites as Fig. 2c shows. The distribution of the absolute difference is centered to the right, indicating higher OMI AODs on average.

The discrimination by $N_{\mathrm{OMI}}$ appears to help in determining possible cloud-contaminated pixels. This approach is a variant of other similar approaches in MODIS aerosol algorithm (Martins et al., 2002). However, it should be noted that even by selecting with $N_{\mathrm{OMI}}=8$, OMI overestimations with respect to AERONET remain. This is illustrated in Fig. 3 where AODs are segregated by the aerosol type as deter- mined by the OMI algorithm and only those points with $N_{\mathrm{OMI}}=8$ are shown. For both aerosol types, OMI overestimates are apparent, even after applying the most stringent criteria in $N_{\mathrm{OMI}}$. Underestimates are most notable in the case of dust aerosols, whereas there are none in the smoke aerosols case.

Overall, depending on the $N_{\mathrm{OMI}}$ threshold applied in the pixel discrimination, 40 to $57 \%$ points are within the uncertainty envelope. This study reports more outliers than Ahn et al. (2014). The discrepancy is expected because the Ahn et al. (2014) study included more continental than marine sites that are more likely to have cloud contamination.

\section{Effect of cloud contamination on the AOD retrieval}

\subsection{Analysis of MODIS and OMI collocated AODs}

To illustrate the impact of cloud contamination in detail, a case of dust over the North Atlantic Ocean is described in this section. The RGB (or visible) image (Fig. 4a) from MODIS provides the context for the retrievals shown next. The AAI (Fig. 4b, OMI orbit no. 22663) is computed in every pixel including in cloudy sectors as can be assessed by comparing with the MODIS RGB. The general location of the dust cloud is better seen in the AAI image and the MODIS AOD image (Fig. 4d). The MODIS AODs show a wide range of values with several patches with no retrievals due to the presence of water clouds. Comparison between OMI and MODIS images demonstrates that the AAI varies in magnitude with the type of underlying background (clouds, dark ocean or mixtures of both) under the dust as well as whether there is dust (or an absorbing aerosol) present. The low AAI (<0.8) coincides with the clear sky patches (according to MODIS) and low MODIS AOD. Where the AAI is high $(>1)$, it tends to 

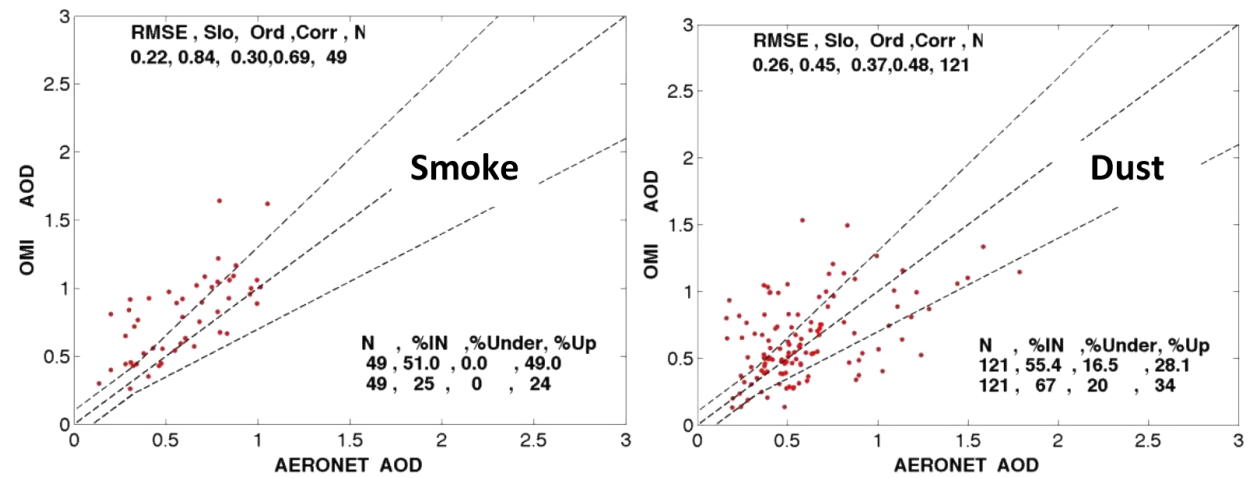

Figure 3. OMI vs. AERONET AOD $380 \mathrm{~nm}$. Same data points and statistics from Fig. $2 \mathrm{~b}$ but segregated by aerosol type as determined by the OMAERUV algorithm and screened by number of successful OMI retrievals surrounding the comparison pixels (only pixels with eight successful retrievals around the selected pixel are used in the comparison).

be higher in cloudy patches than in clear sky patches. This is caused by enhancement of aerosol absorption due to the presence of bright background underneath. The higher AAI over clouds due to the presence of an absorbing aerosol is the physical principle used in the remote sensing of AOD above clouds (Torres et al., 2012).

Figure $4 \mathrm{c}$ shows the operational OMI AOD388 derived in the pixels with flag 0 and by comparing with the MODIS AODs, it is clear that the OMI algorithm screens out many more pixels than MODIS. The main reason is that the algorithm only selects those points with AAI $>0.8$ as candidates for aerosol retrievals and, in addition it removes those that are possibly cloud-contaminated. This image also shows the initial stages of the Row Anomaly (vertical streaks) making a few rows of pixels unsuitable for evaluation of aerosol content.

Figure 5 shows the relative difference of AODs for all collocations as a function of the MODIS CF for this scene. The points are colored by the number of MODIS pixels ( $N_{\mathrm{MOD}}$ ) immediately surrounding the selected pixel (out of 8) with a $\mathrm{CF}>0.3$. The inclusion of surrounding MODIS pixels in the analysis permits the screening of clouds that may be inside the OMI pixel but are not inside the closest MODIS pixel, which is used to compare with the OMI AOD. Thus, a low $\mathrm{CF}$ in the selected MODIS pixel and a low $N_{\mathrm{MOD}}$ gives a very high confidence of an OMI pixel with no clouds in it.

Most of the AODs are within the expected uncertainty envelope. However, the OMI AOD retrievals are larger than MODIS as CF increases. If only considering CF below $0.3-$ 0.4 , there is no trend in the relative difference. In the range $\mathrm{CF}=0.1$ to 0.5 , there are several pixels with large and positive relative difference (30 to $60 \%$ ). However, the respective $N_{\text {MOD }}$ values are high ( $\left.>4\right)$, suggesting that the surrounding MODIS pixels have clouds and are probably contaminating the OMI pixel. In addition, some of the points with very high relative differences and $\mathrm{CF}<0.1$ are pixels at the edge of the OMI swath where the increase of pixel size is so large that even accounting for the immediate MODIS pixels is not
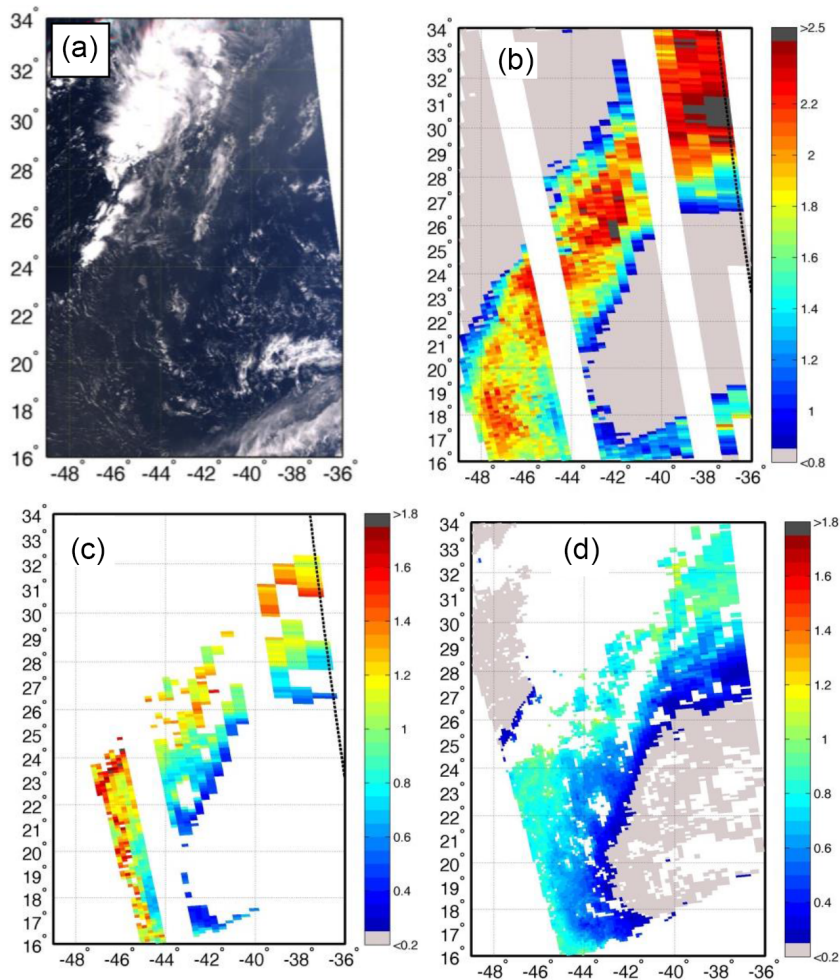

Figure 4. (a) RGB image for MODIS on 11 October 2008 (16:30 UTC) over the N. Central Atlantic. (b) Absorbing Aerosol Index (c) OMI operational AOD $388 \mathrm{~nm}$ (d) MODIS AOD $500 \mathrm{~nm}$. The dashed line is the east edge of the OMI orbit. Pixels with no retrieval are colored white. Pixels in gray are those below the respective color bar minimum.

enough to screen out the OMI contaminated pixels. Overall, this image illustrates that segregation by the cloud fraction of the closest MODIS pixel is useful to screen out most of the contaminated OMI pixels. As a more conservative approach, the CF from the surrounding MODIS pixels can be considered. 


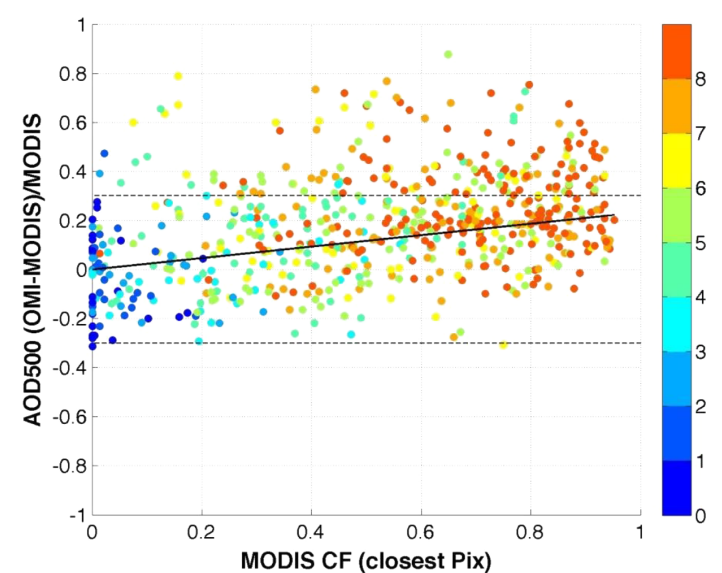

Figure 5. Relative difference of OMI and MODIS (at $500 \mathrm{~nm}$ ) AODs as a function of the cloud fraction in the MODIS retrieval (MODIS aerosol algorithm). The cloud contamination outside the selected MODIS pixel but still within the OMI pixel is represented by the color bar. It displays the number of immediate MODIS pixels around the selected one with $\mathrm{CF}>0.3$ (out of eight surrounding). This figure demonstrates that OMI retrieves a larger AOD than MODIS as cloud fraction increases.

Figure 6a-c quantitatively compare the AODs derived by both algorithms for all pixels with OMI flag 0 . The color in each point is the AAI for the pixel and the dashed lines are the nominal uncertainty for the OMI AOD. Of the 631 points displayed in Fig. 6a, $516(81 \%)$ are within the uncertainty envelope. Figure $6 \mathrm{~b}$ only shows those overlaps with $\mathrm{CF}>0.5$, whereas Fig. $6 \mathrm{c}$ shows overlaps with $\mathrm{CF}<0.3$. Figure $6 \mathrm{~b}$ demonstrates that a significant large number of overlaps above the 1-to-1 line (including those within the $30 \%$ uncertainty) seem to contain clouds. Out of the 336 points displayed, $85(25 \%)$ of them exceed the uncertainty envelope.

If pixels with $\mathrm{CF}>0.3$ are screened out, a very good comparison is achieved (Fig. 6c) with significantly fewer outliers. Out of the 166 points displayed, 12 (7\%) are above the error bounds. Some of these outliers have large OMI AOD values $(>1.0)$ for MODIS AOD $(\sim 0.7-0.9)$ and they are pixels located at the edge of the OMI swath (row $>55$ ) where CF of a single MODIS pixel may not be enough to assess the cloudiness within the OMI pixel.

This analysis suggests that OMAERUV pixels with flag 0 may still be affected by low levels of residual cloud contamination. Using MODIS CF to screen out the OMI cloudcontaminated pixels can improve the statistics of the OMIMODIS comparison but it excludes a significant number of OMI AOD retrievals that otherwise agree well with MODIS observations. It appears that MODIS CF alone, without a qualification on the strength of the cloud signal in terms of, for example reflectance or cloud optical depth, is not sufficient to exclude cloud-contaminated OMI pixels without a significant loss of apparently good-quality OMI retrievals. In addition, it is clear in Fig. $6 \mathrm{~b}$ and $6 \mathrm{c}$ that pixels with high
CF tend to have high AAI (Fig. 6b). High AAI does not always imply that the there is a high concentration of absorbing aerosol. In many cases, it is an indication of the presence of absorbing aerosols above clouds.

In addition, inspection of the number of OMI retrievals around the pixels used in Fig. 6 showed a high number of OMI AOD retrievals around the selected pixel (i.e., $N_{\text {OMI }}>4$ ) and there was no difference in $N_{\text {OMI }}$ between those pixels inside or above the uncertainty envelope (not shown). In this case, it appears that discrimination of OMI pixels by using the number of surrounding retrievals did not help to remove cloud-contaminated pixels.

\subsection{Small clouds within the OMI pixel}

The presence of small clouds in the OMI pixel can be confirmed by inspecting high spatial resolution MODIS imagery with the OMI pixel grid in detail. Figure 7 illustrates a common situation found in the marine environment. The image is a $500 \mathrm{~m}$ resolution MODIS RGB for a dust event off the coast of Morocco where the OMI pixel corners are overlapped. It shows the transition from a dust layer above small fair weather clouds in the boundary layer to dust and no clouds and then to background conditions with no clouds in the northwest corner. The red lines are the OMI pixel edges (rows 43 to 47). The yellow numbers are the OMI AAI (left) and AOD388 (right) found by the OMAERUV algorithm. Pixels with no AOD are pixels where the algorithm considered there were not enough absorbing aerosols for a retrieval $(\mathrm{AAI}<0.8)$ or the AAI was high but the pixel was probably considered to be cloud-contaminated (such as in the lower right corner of the image). The first column of pixels in the west edge is impacted by the Row Anomaly.

The visual comparison of the OMI grid along with the high-resolution MODIS image confirms the following.

1. The AAI has higher values when there are clouds and dust inside the OMI pixel. The observed increasing AAI pattern with $\mathrm{CF}$ indicates that the absorbing dust layer is located above clouds. As noted earlier, the higher AAI is a result of the enhanced absorption due to a brighter background (Torres et al., 2012); that is, it is not due to an increase in aerosol concentration or aerosol height since none of these could change so drastically from one OMI pixel to the other.

2. The OMI algorithm performs aerosol retrievals because of the unambiguous presence of absorbing aerosols in the scene (given by the AAI), even when it is visually clear that the pixel is cloud-contaminated. This condition highlights, on the one hand, the UV capability of aerosol detection above clouds, and on the other hand, the instrumental inability to resolve the subpixel contamination due to the coarse spatial resolution. This scene demonstrates a situation where the evaluation of number of OMI retrievals around the selected 

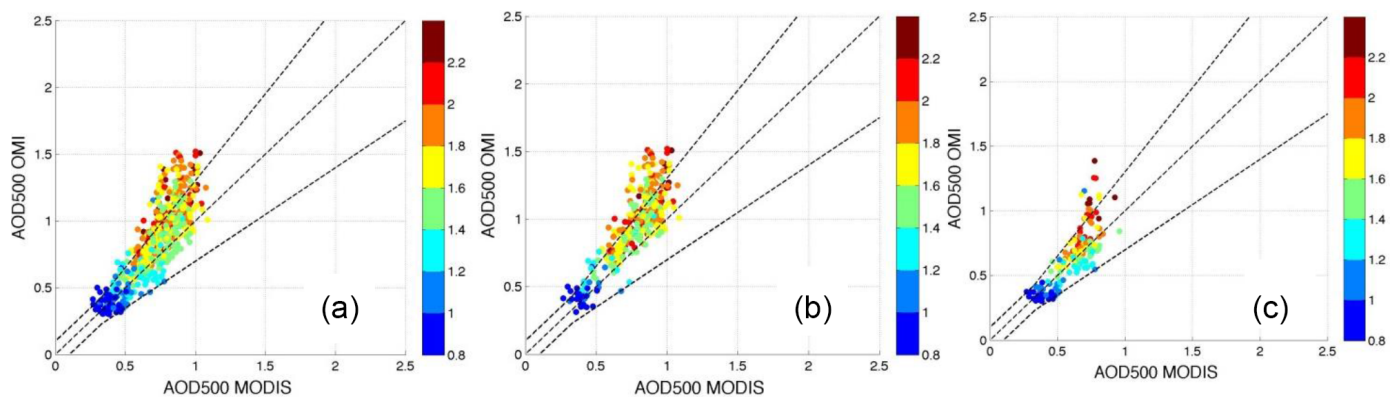

Figure 6. Comparison of OMI AOD $500 \mathrm{~nm}$ and MODIS AOD $500 \mathrm{~nm}$ colored by the corresponding AAI. OMI pixels have flag 0. (a) All points where a successful MODIS and OMI retrieval occurred regardless of the cloud fraction value in the MODIS retrieval. (b) Only points with $\mathrm{CF}>0.5$. (c) Only points with $\mathrm{CF}<0.3$.

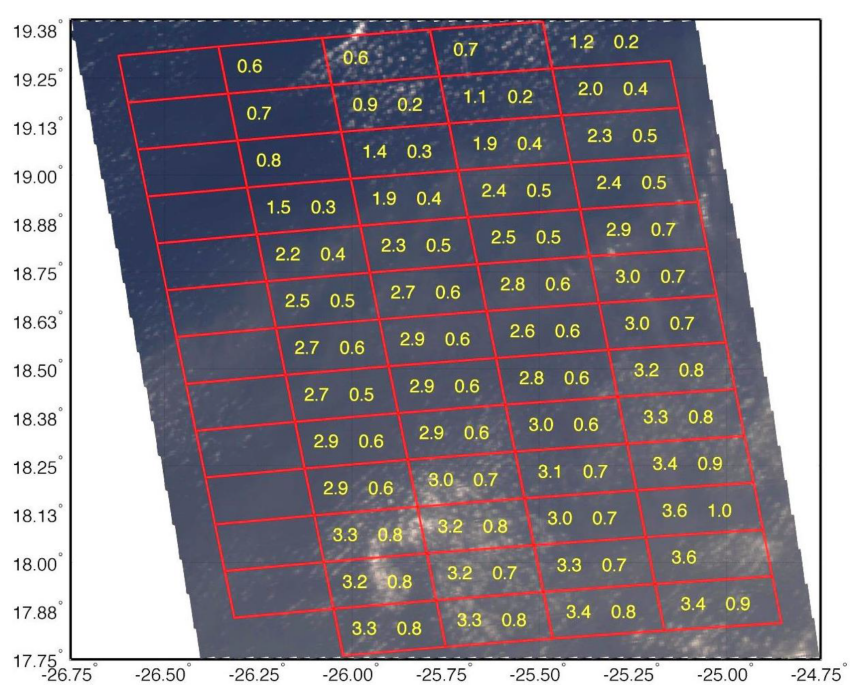

Figure 7. Zoom of the north edge of a dust cloud over the North Atlantic (off the coast of Morocco, 6 June 2012, MODIS 15:15 UTC). Overlapped in red are the OMI pixels' geometrical coordinates (rows 43-47, from left to right) with OMI AAI (left) and OMI AOD388 (right).

pixel ( $N_{\mathrm{OMI}}$ ) may not be effective at determining possible cloud contamination. In this case, several contiguous pixels with clouds have successful AOD retrievals (i.e., $N_{\mathrm{OMI}}$ is high). The combined radiance from clear and cloud sectors within the OMI pixel is not high enough to exceed the threshold reflectance used by the OMAERUV algorithm. A similar type of cloud field (low-altitude fair weather marine cumuli) was also present in Fig. $4 \mathrm{a}$ in the areas with several contiguous OMI AOD retrievals. The contrast in using $N_{\text {OMI }}$ between this case and the comparison with AERONET AODs (Sect. 3) highlights the relative utility of this parameter as a tool for cloud contamination discrimination. Clearly, additional analysis is needed to determine its usefulness.
3. The image also shows that there can be high AAIs, no clouds and moderate values of AODs, indicating that the algorithm is not obviously biased towards retrieving high AODs when the AAIs are high.

This example demonstrates the behavior of the OMAERUV algorithm in partially cloud and clear sky scenes. The usage of collocated MODIS high spatial resolution illustrates the subpixel structure in an OMI pixel, and can aid the OMI retrieval to screen for the presence of clouds not captured by the algorithm.

\section{Analysis of case studies}

The purpose of this section is to illustrate how the AAI and the aerosol retrievals are impacted by changes in the aerosol location in the vertical column and concentration. Both cases are clear sky examples over the ocean.

In the presence of absorbing aerosols over the ocean, and after the OMAERUV algorithm makes a choice of aerosol model, the remaining factors affecting the AOD and SSA retrieval are the location in the vertical column and spectral dependence of the imaginary refractive index. The latter is assumed by prescribing the aerosol types (Torres et al., 2007, 2013). The vertical distribution of the aerosol concentration can be highly variable in ways that sometimes are not well captured by the aerosol height climatology. This is relevant when considering an AERONET-OMI comparison, as in Fig. 3 where it is difficult to assess whether the cause of the underestimate in the OMI algorithm is in the aerosol height assumption or in the microphysical aerosol properties assumed. Unfortunately, coincidental OMI-CALIOP overpasses by AERONET sites are too few for such a comparison. Thus, the source of the discrepancies is searched by examining two case studies (one with and another without underestimates) in detail where collocated MODIS, OMI and CALIOP observations are available. 

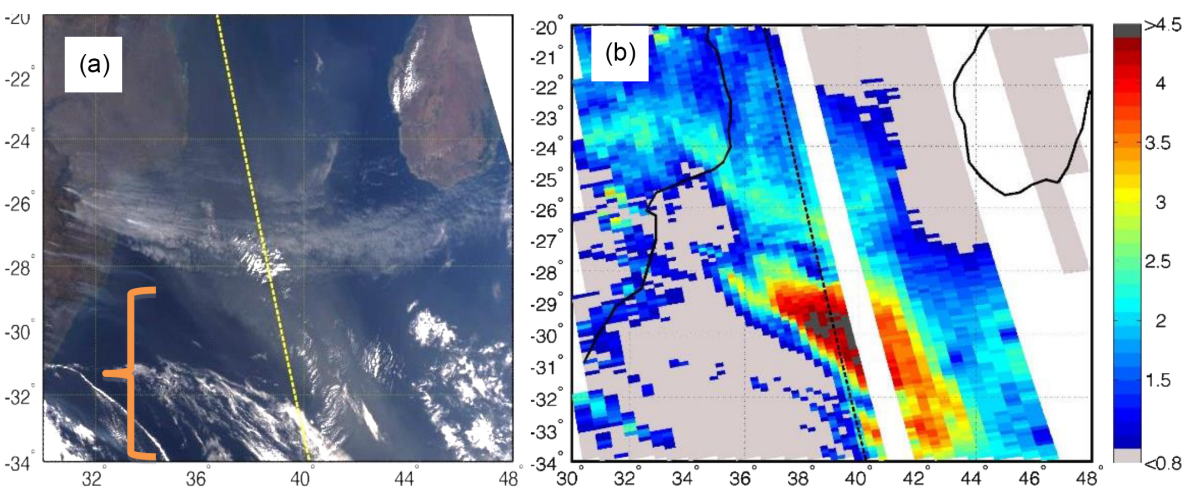

Figure 8. A case of thick smoke over the ocean as seen by OMI and MODIS (a) MODIS RGB image for 31 August 2008 (11:25 UTC) off the coast of SE Africa. The yellow line is the CALIOP track and the bracket indicates the sector that is analyzed in detail in Fig. 10. (b) Corresponding OMI Aerosol Index (CALIOP track in black).
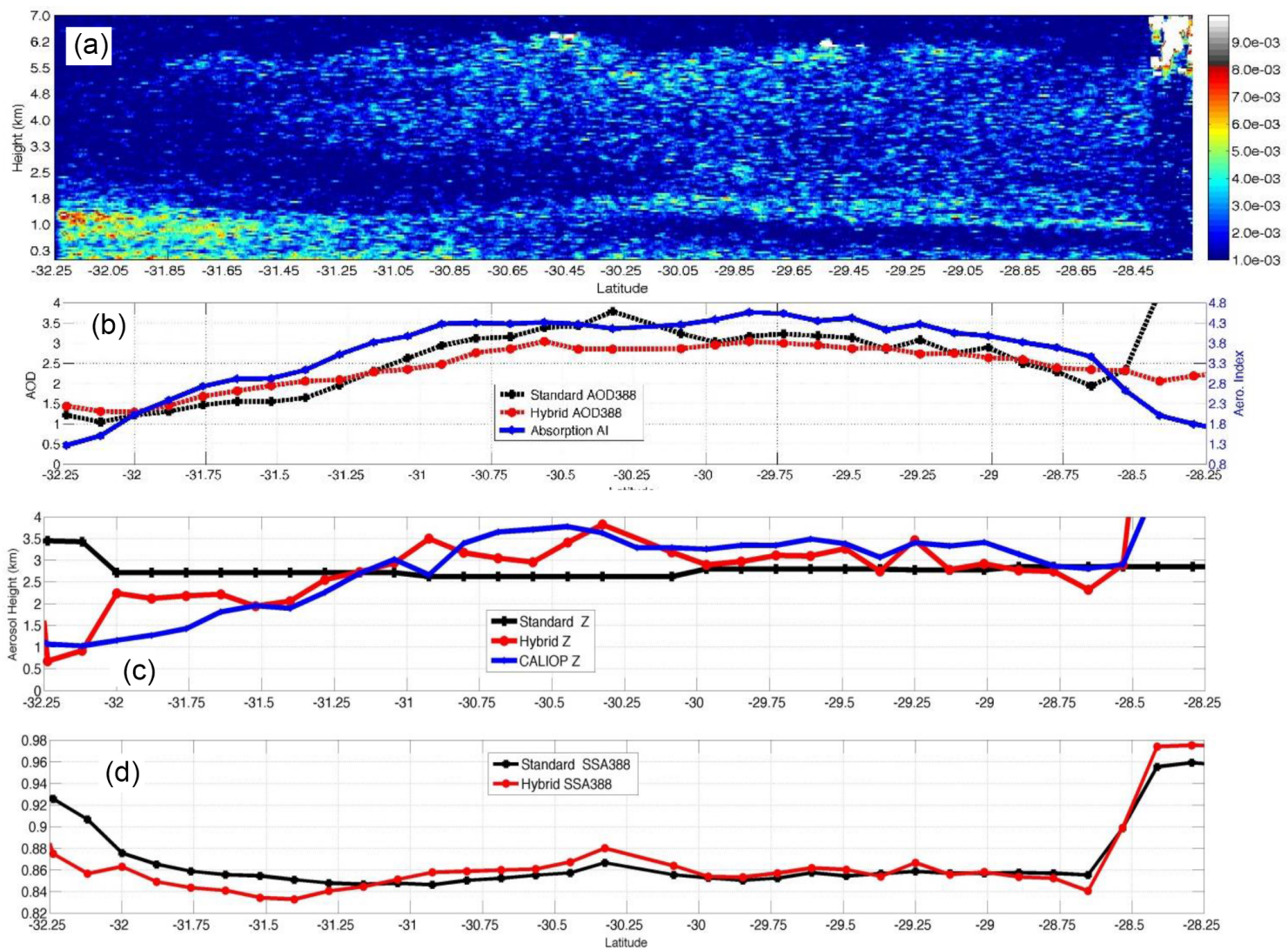

Figure 9. OMI and MODIS retrievals along the CALIOP profile in the south sector of Fig. 8a. The CALIOP 1064 nm attenuated backscattering profile (a) shows two distinct aerosol layers: one near the surface $(0-1.6 \mathrm{~km})$ to the south and an elevated layer in the north section (1 to $6 \mathrm{~km}$ ). (b) shows the MODIS-extrapolated or hybrid (red) and standard OMAERUV (black) AOD388 along with the AI (blue). (c) shows the aerosol layer assumed by the OMAERUV algorithm (black), obtained directly from CALIOP in (a) (blue) and using the hybrid method (red). (d) displays the SSA388 from OMAERUV (black) and from the hybrid method (red).

\subsection{Smoke off southern Africa}

Figure 8a shows a MODIS RGB image in the area off the coast of the southern Africa region. In this example, a thick smoke cloud dominates most of the central part of the im- age. The north-south yellow line is the CALIOP track. Figure $8 \mathrm{~b}$ is the OMI AAI (orbit 21963), showing two regions where absorbing aerosols are present. The AAI values are much higher in the south end (AAI> 2.5) and a section with lower AAI values is located to the north. The coincident 
CALIOP overpass (Fig. 9a) shows the corresponding attenuated backscattering for the south section noted with brackets in Fig. 8a. There are two distinct aerosol layers. In the southernmost section, there is a low-altitude aerosol layer, extending from the surface to $\sim 1.7 \mathrm{~km}$ high. In the $\mathrm{N}-\mathrm{S}$ direction, this layer extends northward up to $-31.2^{\circ}$. At the same latitude, a much higher altitude layer appears, reaching $6.1 \mathrm{~km}$ and with increasing thickness and aerosol concentration from south to north. Almost no clouds are present and the variability in the aerosol layer provides a good opportunity to analyze how the OMAERUV algorithm performs in this scene.

The standard and hybrid AODs (Fig. 9b) are shown along with the AAI (blue line, right $y$ axis). The AAI gradually increases from south to north, peaking with values above 4.5 and then gradually decreasing until $-28.25^{\circ}$ where a group of clouds begin. Both AODs have similar magnitudes and change along with the AAI.

The comparison between the Fig. 9a and b provides a good example on how the AAI behaves upon the change of aerosol height and concentration. At the southern end where the lowaltitude layer is present, both AODs are high $(>1)$ and the AAI hovers around 1-1.5. Although this aerosol layer appears disconnected with the layer aloft, suggesting a different air mass, the lower layer aerosol has a very high finemode fraction ( $>0.9)$ according to MODIS, suggesting that it is smoke too (not shown). The observed low AAI value is the result of the known height dependence (Torres et al., 1998) that yields low values when absorbing aerosol layers are close to the surface. This is an expected behavior of the AAI.

Figure 9c illustrates the changes in aerosol height in a more quantitative manner. The $Z_{\mathrm{c}-\text { inst }}$ (see Sect. 2.4 for definition) is quite different from the $Z_{\mathrm{c}-\mathrm{clm}}$ value assumed by OMAERUV. Differences as large as $2.5 \mathrm{~km}$ can be observed at the southernmost end. The two heights converge towards the thicker end of the aerosol layer to similar values at $-31^{\circ}$. Further north, $Z_{\mathrm{c}-\text { inst }}$ exceeds $Z_{\mathrm{c}-\mathrm{clm}}$ by just less than $0.8 \mathrm{~km}$ for the rest of the CALIOP profile.

Figure 9d shows SSA from the operational and the hybrid retrievals. This figure illustrates the impact of the aerosol height assumed by the OMAERUV algorithm in the retrieved SSA. At the south end where the $Z_{\mathrm{c}-\mathrm{clm}}>Z_{\mathrm{c}-\text { inst }}$, a high SSA value was retrieved. In this case, the hybrid algorithm selects a lower aerosol layer and slightly lower SSA.

Overall, this example illustrates the multiple dependencies of the observed radiances (represented by the AAI), AOD and SSA, which must be accounted for by the retrieval. Along most of the CALIOP profile in Fig. 9a, the OMAERUV algorithm assumed a climatological aerosol layer height $\left(Z_{\mathrm{c}-\mathrm{clm}}\right)$ within $1 \mathrm{~km}$ of the actual CALIOP average height on the day of the observation $\left(Z_{\mathrm{c}-\text { inst }}\right)$ as shown on Fig. 9c. For this reason, there is good agreement between the hybrid and operational AODs and, therefore, only minor adjustments are observed in the $\mathrm{SSA}_{\text {hyb }}$ and $Z_{\text {hyb }}$ re-
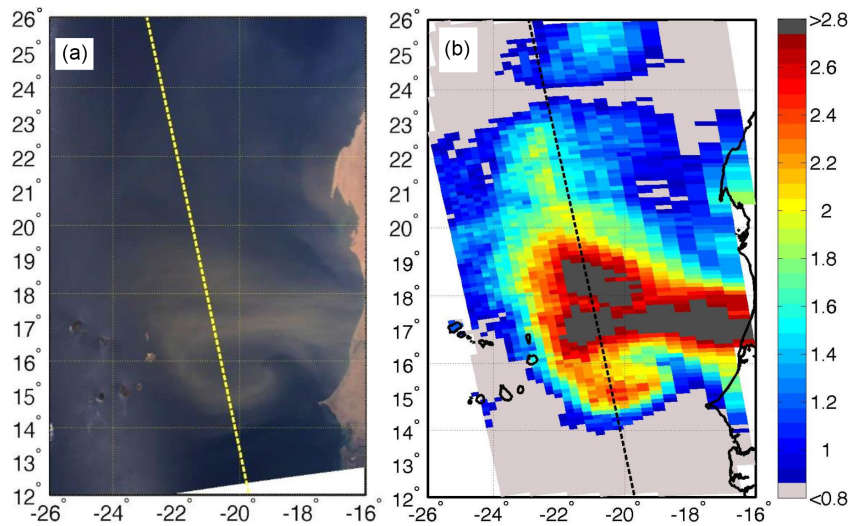

Figure 10. A case of high dust concentrations over the ocean. (a) MODIS RGB image for 9 May 2007 (14:55 UTC) off the coast of NE Africa over the Cabo Verde area. (b) OMI Absorption Aerosol Index. The dashed line in both images is the CALIOP track.

trievals. When the actual aerosol height was different than the climatological value by more than $1.5 \mathrm{~km}$ in the south end, OMAERUV retrieved a markedly higher SSA.

\subsection{High dust concentrations off the coast of Senegal}

Another example is shown to illustrate a case when OMI AODs are low compared with independent measurements. A large and dense dust layer exiting the NE corner of Africa and moving over Dakar and Cabo Verde was well captured by both MODIS and OMI. Figure 10a is the RGB image from the MODIS $1 \mathrm{~km}$ resolution radiances. The collocated OMI AAI image (Fig. 10b, orbit number 14975) shows values between Cabo Verde and the African coast that are much larger than those shown in the previous dust case (Sect. 4). By comparing both images with the RGB image, the highest AAIs are located in the densest area of the dust layer.

The dust layer reached the Cabo Verde AERONET site, raising the AOD at $441 \mathrm{~nm}$ from 1 ( 11:00 UTC) to a maximum of $2.3(\sim 17: 00$ UTC). The coincident MODIS AOD indicates that the densest section of the dust cloud went over the AERONET site with peak AOD of the order of 2.3, indicating agreement between the two different estimates.

The corresponding CALIOP profile is shown in Fig. 11a and it shows a dense dust layer with a top around $2.1-2.3 \mathrm{~km}$ and variable thickness ( 1 to $1.8 \mathrm{~km}$ ). The densest sections of the dust layer can be identified by the white color. While it appears that the dust layer does not reach the ground, there are indications that it may not be the case. Level 2 CALIOP data for this scene identifies several sections at the bottom of the dust layer (coinciding with the section with highest backscattering) as "totally attenuated" (Fig. A1), meaning that there are no laser pulses reaching the detector from these bin heights. CALIOP attenuated profiles can be severely depleted when AODs are higher than 1 (Liu et al., 2011) and, 

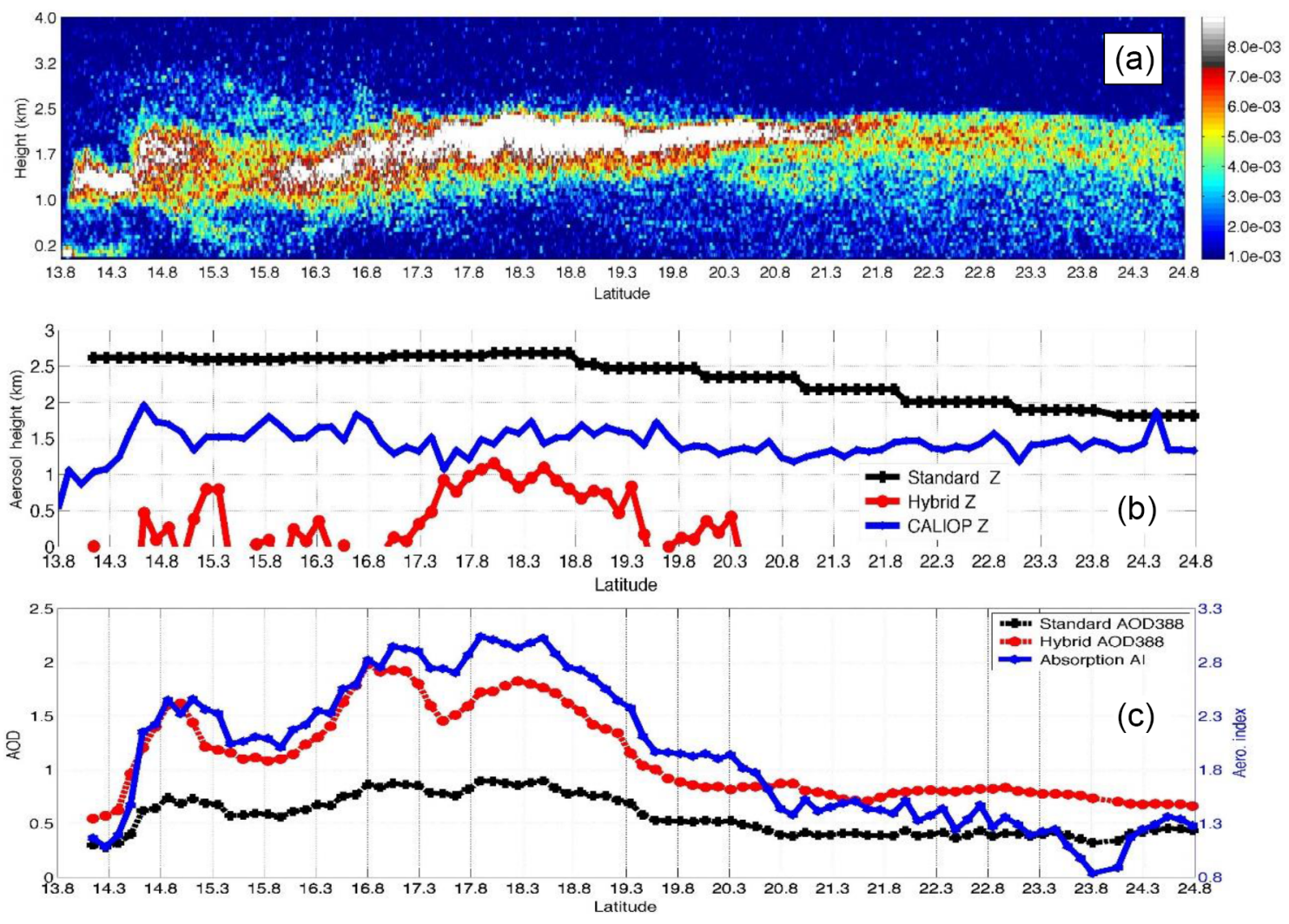

Figure 11. (a) CALIOP profile of the attenuated backscatter (1064 nm, Level 1b) for 9 May 2007. (b) Absorption Aerosol Index (blue, right $y$ axis), OMI and MODIS AODs at $388 \mathrm{~nm}$ (black and red, left- $y$ axis). (c) OMAERUV aerosol height from climatology (black), CALIOP column-integrated attenuated backscattering coefficient $(1064 \mathrm{~nm})$ from (a) (blue) and the hybrid-derived $Z$ (red) following the method of Satheesh et al. (2009).

thus, it is possible that the dust layer extends further down. Figure $11 \mathrm{~b}$ shows the corresponding $Z_{\mathrm{c}-\mathrm{clm}}$ and the actual $Z_{\mathrm{c}-\text { inst }}$. Clearly, the center of the assumed layer height by the operational algorithm is higher than the actual layer location by as much as $1.5 \mathrm{~km}$ in the south end. In contrast, the assumed climatological value is 0.5 to $1 \mathrm{~km}$ higher than the actual average aerosol height in the north end.

The analysis of the standard and hybrid AODs along the CALIOP profile reveals additional features (Fig. 11c) and pinpoints the source of variability in AAI. The hybrid AOD is notably higher than the corresponding operational AOD by factor of 2 or more. The AAI correlates well with the hybrid AOD, whereas the correlation with the operational AOD is not as obvious. Simultaneously, the $Z_{\text {hyb }}$ looks unrealistic (Fig. $11 \mathrm{~b}$, red line). Negative $Z_{\text {hyb }}$ values predominate over most of the CALIPSO transect. In the hybrid retrieval, it is assumed that the difference between OMI operational and MODIS extrapolated AODs is only due to an erroneous assumption on aerosol height by the OMAERUV algorithm. All other possible error sources are ignored. In spite of the use of a realistic AOD, the resulting negative aerosol height values point to other sources of error, such as the parameters of the assumed aerosol model by OMAERUV.
Assuming that the aerosol intensive absorbing properties do not change much along the profile, the observed AAI variability is mainly the result of changes in aerosol concentration, layer thickness and layer height along the transect. Because the hybrid AOD does not depend on layer height, concentration changes alone would explain the observed close MODIS AOD-AAI co-variability in the latitude range $14.3^{\circ} \mathrm{N}$ to near $18.3^{\circ} \mathrm{N}$, where $\mathrm{AAI}>1.8$ and $Z_{\mathrm{c}-\text { inst }}$ is roughly constant (according to CALIOP). In the southern and northern latitude ranges, the AAI is probably sensitive to aerosol height differences. For example, in the south end, the aerosol layer is very dense and at low altitude. In the north end (latitude $>23^{\circ} \mathrm{N}$ ) of Fig. 11b, the aerosol layer is more elevated than in the south end but the aerosol concentrations are much lower (according to MODIS), resulting in a low AAI. This illustrates that a high-altitude absorbing aerosol will not have a high AAI if the concentrations are not sufficiently high.

This is an example where the AAI variability can be attributed to both concentrations and aerosol height variations. It also shows that both altitude and concentration can co-vary in ways that are difficult to resolve. More importantly, the OMI AOD can be significantly underestimated and it can oc- 
cur everywhere in the same event. The large scale of the underestimate suggests that a more systemic effect is at play within the algorithm. While this underestimate does not appear to be too frequent (underestimates are less than $20 \%$ according to Fig. 3b), it is still of interest to find out the root cause. This is explored in the next section.

\section{Source of discrepancy in retrieved AODs}

The origins of the underestimated AODs by the OMAERUV algorithm noted in the previous section are analyzed here. In this section, some of the assumptions made by the retrieval algorithm are specifically tested to verify whether they are fulfilled for the pixels under observation. Based on the independent information available (MODIS, CALIOP, AERONET) the following assumptions made by OMAERUV are considered: (1) aerosol layer height, (2) aerosol particle size distribution, (3) relative spectral dependence (354-388 nm) of the imaginary index of refraction, (4) particle shape assumption.

In order to assess whether an incorrect climatological height can be the cause of the observed difference, the OMAERUV algorithm ingested the OMI radiances of the pixels along the lidar profile. Instead of using the climatological heights, the algorithm was forced to use the actual aerosol height from CALIOP. The calculation indicated that the new OMAERUV AODs were higher than the standard retrieval but not enough to make up for the difference in AODs seen in Fig. 11c.

OMAERUV particle size distributions are static, for example in the case of dust, the bi-lognormal size distribution is fixed and with a constant Ångström exponent (AE) of 0.6 based on the distributions reported by Duvobik et al. (2002). While this assumption seems to work in most cases, it is known that dust $\mathrm{AE}$ can fluctuate (values ranging from -0.5 to 1.0 have been reported in dust, Kim et al., 2011) because of variability in the size distribution (Toledano et al., 2007; Eck et al., 2010) or the distribution may not be bi-lognormal (Gianelli et al., 2013). Radiative transfer simulations were carried out using the OMAERUV dust size distributions and varied the coarse-mode concentration such that the respective $\mathrm{AE}$ ranged between -0.5 and 0.6 . It was found that a model with a lower AE than currently used by OMAERUV would further decrease the retrieved AOD. Thus, the particle dust distribution assumption does not appear to be the source of the observed large AOD underestimate for the case under consideration.

Another test was carried out to evaluate whether the aerosol under observation had a significantly different spectral dependence in the imaginary index of refraction. The dust models have different imaginary indexes with a fixed spectral dependence set by their ratio of imaginary refractive indices $(\operatorname{Img}(354 \mathrm{~nm}) / \operatorname{Img}(388 \mathrm{~nm}))$ to a constant value of 1.4. A simulation with a radiative transfer code was set up using all information available for this scene. The observed radiances for a selected pixel in the area with highest AAI were modeled. A reference case was defined by the independent information available. In this case, an AOD at $500 \mathrm{~nm}$ of 2.21 (from MODIS) and a vertical profile of the aerosols peaking at $1.5 \mathrm{~km}$ (a Gaussian shape with $1 \mathrm{~km}$ standard deviation derived from a curve fit to the actual CALIOP profile) were selected. The simulation of this reference case resulted in radiances that did not match the observed radiances. Only when adjusting the ratio of the imaginary indexes to a much lower value, would the derived radiances match the observed radiances. However, if the ratio were near 0.95, then, a dust model with higher absorption at $388 \mathrm{~nm}$ than at $354 \mathrm{~nm}$ would be required to match the observations. While not common, dust models with a ratio as low as 1.14 have been reported in the literature for Saharan dust samples (Wagner et al., 2012), but the required reverse spectral dependence is not supported by what is known about the absorption properties of dust components. Thus, an incorrect assumption on the spectral dependence of the imaginary index of refraction does not explain the observed discrepancy in AOD.

The next factor examined was the assumption on the shape of desert dust aerosol particles. In the OMAERUV algorithm all aerosol particles are assumed to be spherical. An examination of a phase function plot of a sphere and a spheroid (Mishchenko et al., 1997) aerosol model shows that an important difference exists between the two models in the scattering angle range $100-180^{\circ}$. In the case under consideration (Fig. 10), the scattering angle is in the 150-180 range (Appendix Fig. A2), suggesting that these angle ranges might be impacted by the particle shape assumption. In addition, a previous study of remote sensing of ash in the near-UV (Krotkov et al., 1999) found differences due to the particle shapes in the retrieval. This study utilized a retrieval method based on the ratio of radiances of two wavelengths in the UV very similar to the one used by OMAERUV and found that implementing non-spherical particle size distributions resulted in a much better agreement between observations and modeled radiances.

The impact of particle shape in the OMAERUV retrieval was tested by carrying out retrievals along the CALIOP profile in Fig. 10a. A new non-spherical dust lookup table (LUT) was generated with the same size distribution and refractive indexes of the existing dust model in OMAERUV. New radiances for the non-spherical ("spheroids") particles at the nodal points were generated by a software package specially designed for non-spherical aerosol models (Duvobik et al., 2006). The distribution of shapes was the one currently used by the AERONET sky radiance inversion algorithm to represent non-spherical dust. The new LUT replaced the spherical dust model in a research version of the OMAERUV algorithm. The research version of the code was run for the observation conditions along the CALIOP profile. Three runs were carried out: (1) a control run using the default spherical models and climatological aerosol height (i.e., equivalent to 

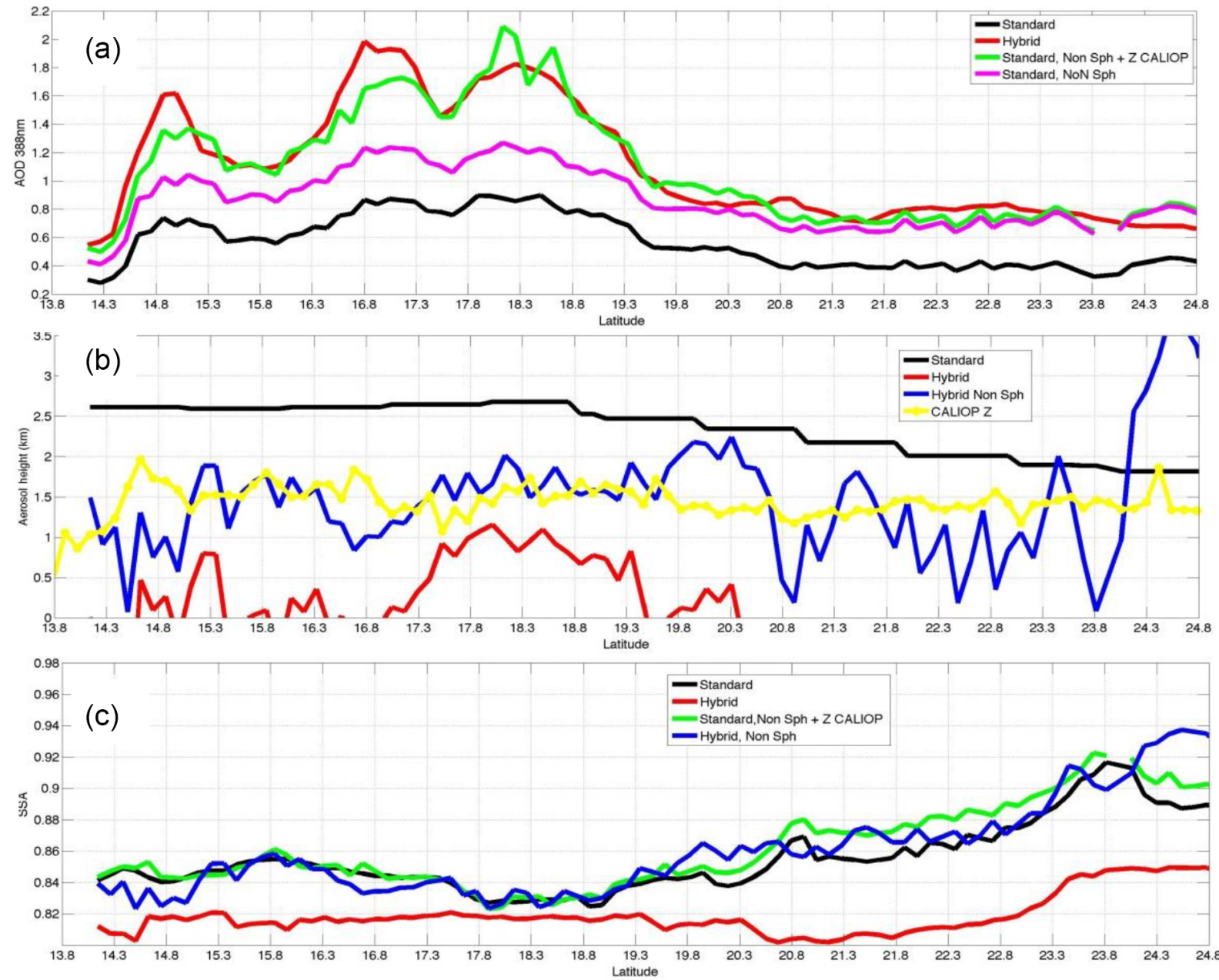

Figure 12. AOD, SSA at $388 \mathrm{~nm}$ and aerosol height derived by different methods. (a) AOD from the OMAERUV (or standard) algorithm using the default particle shape (spheres) and aerosol height (climatology) (in black), using non-spheres and climatological height (pink), using non-spheres and actual aerosol height from CALIOP (green) and the hybrid AOD (red). (b) Climatological aerosol height (black), CALIOP measured aerosol height (yellow), hybrid aerosol height using the spherical (red) and non-spherical (blue) models. (c) SSA from the standard retrieval (black), from standard retrieval using non-sphere models and measured CALIOP height (green), from hybrid retrievals using sphere (red) and non-sphere (blue) models.

the operational retrieval) (2) a run using the spheroidal LUT and the climatological aerosol heights and (3) a run using the spheroidal LUT and the actual aerosol height derived from the CALIOP profile.

The respective AODs, SSAs and heights results are shown along with the hybrid method retrievals in Fig. 12. In Fig. 12a, the incorporation of a non-spherical model (pink line) in the LUT results in a higher AOD than using a spherical model (black). The increase is across the board and is consistent with the expectation given the OMI scattering angle varies just from 170 to $173^{\circ}$ along the CALIOP profile shown. The incorporation of the non-spherical model is enough to make up the difference with the hybrid AOD in the north section. Large differences remain in the southernmost region $\left(14.5\right.$ to $\left.20^{\circ} \mathrm{N}\right)$ where the actual CALIOP aerosol height and the climatological value used by OMAERUV dif- fer by as much as $1.5 \mathrm{~km}$. When the retrieval algorithm includes the non-spherical and the actual aerosol profile derived from CALIOP in this case, a very good match in AOD with the hybrid AOD is achieved (green and red lines in Fig. 12a).

Particle shape impacts the retrieval of aerosol heights by the hybrid method significantly (Fig. 12b). The hybrid retrieval using spherical models (red line) results in unrealistically low heights, even negative values. However, when using the non-spherical model, the aerosol height is closer and more consistent with the actual measurements with CALIOP.

Figure 12c shows the SSA $388 \mathrm{~nm}$ computed using the standard retrieval with spherical model with the climatological height and another case using a non-spherical model with the actual CALIOP height. The hybrid retrievals using the spheres and non-spheres are shown too. In comparing these 
curves, there is no clear true value from which all of them should be compared to. However, from a theoretical view point, particle shape should not impact the SSA retrieval significantly as noted by Kroktov et al. (1999) and Duvobik et al. (2006). The inclusion of a realistic particle shape and aerosol height (green line) does not result in any significant difference with respect to the standard operational retrieval (black). However, the impact is apparent in the absorption AOD. Differences are within the operational uncertainly for OMAERUV SSA retrievals (0.03 in SSA units).

In summary, this analysis showed that the shape assumption in dust models used by OMAERUV is the most important cause of the discrepancies between hybrid and standard AOD retrievals.

\section{Summary of results and recommendations}

This work characterizes the OMI aerosol optical depth (AOD) derived by the two-channel near-UV algorithm (OMAERUV, version 1.4.2) over the ocean and determines the role of aerosol particle shape, aerosol layer height and cloud contamination in the retrievals. This report is structured in three sections. The first one compares several years of collocated OMI and AERONET AODs at $388 \mathrm{~nm}$; the second section evaluates the cloud contamination inside the OMI pixels by collocating with MODIS observations. The third section evaluates the cause of observed underestimation of OMI AODs in certain scenes with dust aerosols.

Comparison at AERONET island and coastal sites (Fig. 2) indicates that $40 \%$ of OMI's ocean retrievals of absorbing aerosols are within the uncertainties defined for the product. OMI aerosol optical depths over the ocean tend to be more cloud-contaminated than retrievals over land. The agreement with AERONET is largely dependent on the cloud contamination in the OMI pixel. It is shown that when OMI overestimates with respect to AERONET, the selected OMI pixel is surrounded by very few successful OMI retrievals. Thus discrimination of the pixels by accounting for the number of surrounding OMI retrievals suggests a possible technique for additional cloud screening of OMI pixels. Overall, the OMAERUV algorithm adequately removes cloudcontaminated pixels. The current retrieval scheme (removal of cloudy pixels based on the value of the observed reflectivity) does an adequate job at retrieving the AOD. The user is advised to only use AOD retrievals with quality flag 0 .

The comparison with collocated AERONET and MODIS data revealed that a minor proportion of the OMI AODs are underestimated. The underestimate appears to be more pronounced when dust aerosols (Fig. 3) are identified by the OMI aerosol algorithm. A detailed examination of a dust case study demonstrated that the assumption of spherical particles in the dust model by the retrieval algorithm was the cause of the underestimation. Further, when a non-spherical correction was applied to the OMI standard retrieval, it became clear that the AOD can still be underestimated if the assumed aerosol height is higher than the actual aerosol height. While this was only verified in a case study, the impact of the nonspherical assumption is significant enough to deserve further evaluation towards incorporating these findings into a future version of the algorithm. This finding illustrates the importance of particle shape in aerosol retrievals in the nearUV range and it demonstrates that one general approach for all aerosol scenes (in this case same shape for all observed aerosol types) is not adequate. A similar problem was found in Wang et al. (2003) when evaluating the performance of retrievals of dust in a simulated GOES-type of detector and in Krotkov et al. (1999) in near-UV retrievals of volcanic ash.

It should be noted that only a fraction of the total dust retrievals carried out by OMAERUV are underestimated. There is an underestimation beyond the uncertainty envelope in dust AOD in less than $20 \%$ of the comparison points. Based on the phase function for spherical and non-spherical shown in Mischenko et al., 1997, it is expected that the difference between spherical and non-spherical dust retrievals will be most pronounced at angles in the 100-180 range and, in particular, underestimates should occur when the angle range is $150-180^{\circ}$. This condition is frequently found in the dust clouds off the coast of Dakar as the example shown here demonstrates.

This study showed the interplay of variable aerosol height and concentration in impacting the magnitude and variability of the Absorbing Aerosol Index. Examples of dust and biomass burning scenes collocated with MODIS AODs and CALIOP attenuated backscattering profiles are shown to illustrate these points. For example, the AAI can have a low magnitude $(<1.5)$ when the aerosol layer is low $(<1.5 \mathrm{~km})$, even though the aerosol concentrations are high (AOD 1) (Fig. 9a and b). These cases demonstrate to the user that the AAI magnitude alone cannot be used quantitatively if no aerosol height or concentration information is available.

The retrieval of aerosol height and single scattering albedo using the method of Satheesh et al. (2009) (the hybrid method) was partially evaluated too. In the two case studies considered, it was found that the retrieved aerosol height compared very well with the CALIOP-derived height in the cases when the AAI was high $(>1.8)$. At lower AAI, it appears the method is very sensitive to small variations in the input AOD used to select the final pair of height and SSA. Clearly additional analysis is needed to determine the AAI magnitude and range of uncertainty in the input AOD when the hybrid method will derive a realistic retrieved height and SSA.

The analysis presented here is based on the current operational version 1.4.2 of the algorithm. The next version of the algorithm will incorporate some of the findings of this work, mainly the incorporation of non-spherical dust models in the lookup table. 


\section{Data availability}

All raw data utilized in this work were obtained from public databases hosted by different NASA centers. CALIOP data were obtained from the NASA Langley Research Center Atmospheric Science Data Center (https://eosweb.larc. nasa.gov/). OMI data were obtained from the NASA Goddard Earth Sciences Data and Information Services Center (doi:10.5067/Aura/OMI/DATA3003). The Aqua/MODIS Atmosphere L2 Aerosol Product (MYD04) was acquired from the Level-1 \& Atmosphere Archive and Distribution System (LAADS) Distributed Active Archive Center (DAAC), located in the Goddard Space Flight Center in Greenbelt, Maryland (doi:10.5067/MODIS/MYD04_L2.006). 


\section{Appendix A}

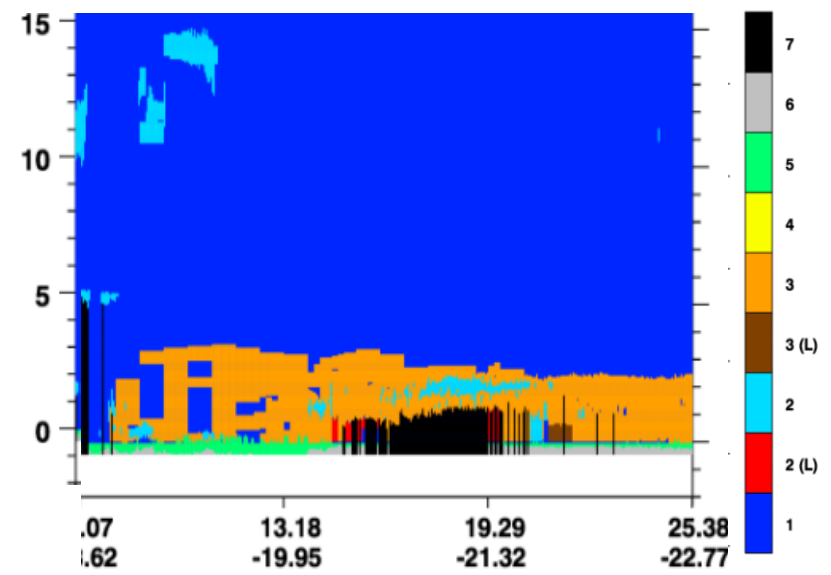

Figure A1. CALIPSO Level 2 Vertical Mask Feature for the 9 May 2007 case study. Color key: 1: clear air, 2: cloud, 3: aerosol, 4: stratospheric layer, 5: surface, 6: subsurface, 7: totally attenuated beam.

OMAERUV Scat Angle OMI-Aura_L2-OMAERUV_2008m1011t1544-022563

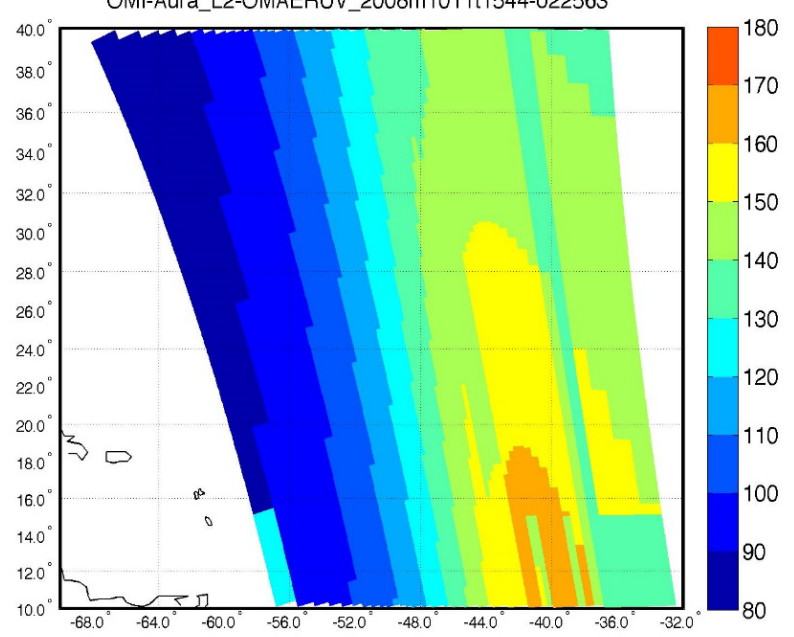

OMAERUV Scat Angle

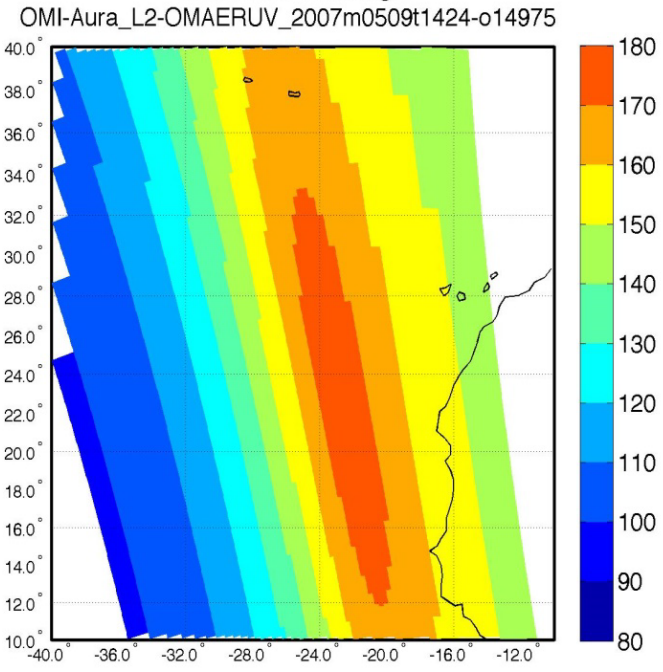

Figure A2. Scattering angles for the two dust case studies: 11 October 2008 (left) and 9 May 2007 (right). 
Table A1. List of AERONET sites used in the comparison with OMI retrievals. Table includes information of the start and end years used in the comparison, location (latitude/longitude), type of sites (coastal/island), country and ocean basin.

\begin{tabular}{|c|c|c|c|c|c|c|c|c|}
\hline No. & AERONET site & Start & End & Latitude & Longitude & Type & Country & Ocean basin \\
\hline 1 & Calhau & 2012 & 2013 & 16.86 & -24.87 & island & Cabo Verde & N Atlantic \\
\hline 2 & Cabo Verde & 2004 & 2013 & 16.73 & -22.94 & island & Cabo Verde & $\mathrm{N}$ Atlantic \\
\hline 3 & Dakar & 2004 & 2013 & 14.39 & -16.96 & coastal & Senegal & N Atlantic \\
\hline 4 & La Laguna & 2006 & 2013 & 28.48 & -16.32 & island & Tenerife & N Atlantic \\
\hline 5 & Santa Cruz, Tenerife & 2004 & 2013 & 28.47 & -16.25 & island & Tenerife & N Atlantic \\
\hline 6 & La Parguera & 2004 & 2013 & 17.97 & -67.05 & island & Puerto Rico & $\mathrm{N}$ Atlantic \\
\hline 7 & Cape San Juan & 2004 & 2013 & 18.38 & -65.62 & island & Puerto Rico & N Atlantic \\
\hline 8 & Camagüey & 2008 & 2013 & 21.42 & -77.85 & island & Cuba & N Atlantic \\
\hline 9 & Tudor Hill & 2007 & 2013 & 32.26 & -64.88 & island & Bermuda & N Atlantic \\
\hline 10 & Guadeloupe & 2004 & 2013 & 16.33 & -61.5 & island & Antilles & N Atlantic \\
\hline 11 & Ragged Point & 2007 & 2013 & 13.16 & -59.43 & island & Bahamas & N Atlantic \\
\hline 12 & Forth Crete & 2004 & 2013 & 35.33 & 25.28 & island & Crete & Mediterranean Sea \\
\hline 13 & Lampedusa & 2004 & 2013 & 35.52 & 12.63 & coastal & Italy & Mediterranean Sea \\
\hline 14 & Sagres & 2010 & 2013 & 37.05 & -8.87 & coastal & Portugal & $\mathrm{N}$ Atlantic \\
\hline 15 & El Arenosillo & 2004 & 2010 & 37.1 & -6.73 & coastal & Spain & N Atlantic \\
\hline 16 & Ascension Island & 2004 & 2013 & -7.98 & -14.41 & island & England & Equatorial Atlantic \\
\hline 17 & Dhadnah & 2004 & 2010 & 25.51 & 56.32 & coastal & UAE & Persian Gulf \\
\hline 18 & KAUST campus & 2012 & 2013 & 22.3 & 39.1 & coastal & Saudi Arabia & Red Sea \\
\hline 19 & Bahrain & 2004 & 2006 & 26.21 & 50.61 & coastal & Bahrain & Persian Gulf \\
\hline 20 & Karachi & 2006 & 2013 & 24.87 & 67.03 & coastal & Pakistan & Arabian Sea \\
\hline 21 & Anmyon & 2004 & 2007 & 36.54 & 126.33 & coastal & S Korea & Yellow Sea \\
\hline 22 & Gosan SNU & 2004 & 2013 & 33.29 & 126.16 & island & S Korea & Yellow Sea \\
\hline 23 & Baengnyeong & 2010 & 2012 & 37.97 & 124.63 & coastal & S Korea & Yellow Sea \\
\hline 24 & Fukue & 2012 & 2013 & 32.75 & 128.68 & island & Japan & East China Sea \\
\hline 25 & Dongsha Islands & 2009 & 2013 & 20.7 & 116.73 & island & Taiwan & South China Sea \\
\hline 26 & Songkhla & 2007 & 2013 & 7.18 & 100.6 & coastal & Thailand & Gulf of Thailand \\
\hline 27 & Nha Trang & 2011 & 2013 & 12.2 & 109.21 & coastal & Vietnam & South China Sea \\
\hline 28 & Pontianak & 2012 & 2013 & 0.08 & 109.19 & coastal & Indonesia & Java Sea \\
\hline 29 & MCO & 2004 & 2013 & 6.78 & 73.18 & island & Maldives & Indian Ocean \\
\hline 30 & Reunion & 2004 & 2013 & -20.88 & 55.48 & island & France & SW Indian Ocean \\
\hline 31 & Crozet Islands & 2004 & 2013 & -46.43 & 51.85 & island & France & SW Indian Ocean \\
\hline 32 & Tahiti & 2004 & 2010 & -17.58 & -149.61 & island & France & S Pacific Ocean \\
\hline 33 & Manus & 2010 & 2013 & -2.06 & 147.43 & island & Papua New Guinea & Eq. Pacific Ocean \\
\hline
\end{tabular}


Acknowledgements. This work was carried out under NASA funding from the Aura Project managed by Ken Jucks. The authors wish to thank Oleg Duvobik for providing the spheroid scattering code and Hiren Jetvha for generating lookup tables for the calculations used in this paper.

Edited by: F. Boersma

\section{References}

Ahn, C., Torres, O., and Bhartia, P. K.: Comparison of Ozone Monitoring Instrument UV Aerosol Products with Aqua/Moderate Resolution Imaging Spectroradiometer and Multiangle Imaging Spectroradiometer observations in 2006, J. Geophys. Res., 113, D16S27, doi:10.1029/2007JD008832, 2008.

Ahn, C., Torres, O., and Jethva, H.: Assessment of OMI near-UV aerosol optical depth over land, J. Geophys. Res.-Atmos., 119, doi:10.1002/2013JD020188, 2014.

Bond, T. C., Doherty, S. J., Fahey, D. W., Forster, P. M., Berntsen,T., DeAngelo, B. J., Flanner, M. G., Ghan, S., Kärcher, B., Koch,D., Kinne, S., Kondo, Y., Quinn, P. K., Sarofim, M. C., Schultz,M. G., Schulz, M., Venkataraman, C., Zhang, H., Zhang, S.,Bellouin, N., Guttikunda, S. K., Hopke, P. K., Jacobson, M.Z., Kaiser, J. W., Klimont, Z., Lohmann, U., Schwarz, J. P.,Shindell, D., Storelvmo, T., Warren, S. G., and Zender, C. S.: Bounding the role of black carbon in the climate system: A scientific assessment, J. Geophys. Res.-Atmos., 118, 5380-5552, doi:10.1002/jgrd.50171, 2013.

Buchard, V., da Silva, A. M., Colarco, P. R., Darmenov, A., Randles, C. A., Govindaraju, R., Torres, O., Campbell, J., and Spurr, R.: Using the OMI aerosol index and absorption aerosol optical depth to evaluate the NASA MERRA Aerosol Reanalysis, Atmos. Chem. Phys., 15, 5743-5760, doi:10.5194/acp-15-57432015, 2015

Carn, S., Arlin, A., Krueger, J., Krotkov, N. A., Yang, K., and Evans, K.: Tracking volcanic sulfur dioxide clouds for aviation hazard mitigation, Nat. Hazards, 51, 325-343, doi:10.1007/s11069-0089228-4, 2008

Castellanos, P., Boersma, K. F., Torres, O., and de Haan, J. F.: OMI tropospheric $\mathrm{NO}_{2}$ air mass factors over South America: effects of biomass burning aerosols, Atmos. Meas. Tech., 8, 3831-3849, doi:10.5194/amt-8-3831-2015, 2015.

Chen, W.-T., Kahn, R. A., Nelson, D., Yau, K., and Seinfeld, J. H.: Sensitivity of multiangle imaging to the optical and microphysical properties of biomass burning aerosols, J. Geophys. Res., 113, D10203, doi:10.1029/2007JD009414, 2008.

Chen, Z., Torres, O., McCormick, M. P., Smith, W., and Ahn, C.: Comparative study of aerosol and cloud detected by CALIPSO and OMI, Atmos. Environ., 51, 187-195, doi:10.1016/j.atmosenv.2012.01.024, 2012.

Chin, M., Diehl, T., Tan, Q., Prospero, J. M., Kahn, R. A., Remer, L. A., Yu, H., Sayer, A. M., Bian, H., Geogdzhayev, I. V., Holben, B. N., Howell, S. G., Huebert, B. J., Hsu, N. C., Kim, D., Kucsera, T. L., Levy, R. C., Mishchenko, M. I., Pan, X., Quinn, P. K., Schuster, G. L., Streets, D. G., Strode, S. A., Torres, O., and Zhao, X.-P.: Multi-decadal aerosol variations from 1980 to 2009: a perspective from observations and a global model, Atmos. Chem. Phys., 14, 3657-3690, doi:10.5194/acp-14-3657-2014, 2014.
Curier, R. L., Veefkind, J. P., Braak, R., Veihelmann, B., Torres, O., and de Leeuw, G.: Retrieval of aerosol optical properties from OMI radiances using a multiwavelength algorithm: Application to western Europe, J. Geophys. Res., 113, D17S90, doi:10.1029/2007JD008738, 2008.

Dubovik, O., Holben, B., Eck, T. F., Smirnov, A., Kaufman, Y. J., King, M. D., Tanre, D., and Slutsker, I.: Variability of absorption and optical properties of key aerosol types observed in worldwide locations, J. Atmos. Sci., 59, 590-608, 2002.

Dubovik, O., Sinyuk, A., Lapyonok, T., Holben, B. N., Mishchenko, M., Yang, P., Eck, T. F., Volten, H., Muñoz, O., Veihelmann, B., van der Zande, W. J., Leon, J.-F., Sorokin, M., and Slutsker, I.: Application of spheroid models to account for aerosol particle nonsphericity in remote sensing of desert dust, J. Geophys. Res., 111, D11208, doi:10.1029/2005JD006619, 2006.

Duncan, B. N., Prados, A. I., Lamsal, L. N., Liu, Y., Streets,D. G., Gupta, P., Hilsenrath, E., Kahn, R. A., Nielsen, J. E., Beyersdorf, A. J., Burton, S. P., Fiore, A. M., Fishman, J., Henze, D. K., Hostetler, C. A., Krotkov, N. A., Lee, P., Lin, M., Pawson, S., Pfister, G., Pickering, K. E., Pierce, R. B., Yoshida Y., and Ziemba, L. D.: Satellite data of atmospheric pollution for U.S. air quality applications: Examples of applications, summary of data end-user resources, answers to FAQs, and common mistakes to avoid, Atmos. Environ., 94, 647-662, doi:10.1016/j.atmosenv.2014.05.061, 2014.

Eck, T. F., Holben, B. N., Sinyuk, A., Pinker, R. T., Goloub, P., Chen, H., Chatenet, B., Li, Z., Singh, R. P., Tripathi, S. N., Reid, J. S., Giles, D. M., Dubovik, O., O’Neill, N. T., Smirnov, A., Wang, P., and Xia, X.: Climatological aspects of the optical properties of fine/coarse mode aerosol mixtures, J. Geophys. Res., 115, D19205, doi:10.1029/2010JD014002, 2010.

Genkova, I., Robaidek, J., Roebling, R., Sneep, M., and Veefkind, P.: Temporal co-registration for TROPOMI cloud clearing, Atmos. Meas. Tech., 5, 595-602, doi:10.5194/amt-5-595-2012, 2012.

Gianelli, S. M., Lacis, A. A., Carlson, B. E., and Hameed, S.: Evidence of a weakly absorbing intermediate mode of aerosols in AERONET data from Saharan and Sahelian sites, J. Geophys. Res. Atmos., 118, 12661-12672, doi:10.1002/2013JD020342, 2013.

Gómez-Amo, J. L., di Sarra, A., Meloni, D.: Sensitivity of the atmospheric temperature profile to the aerosol absorption in the presence of dust, Atmospheric Environment, 98, 331-336, doi:10.1016/j.atmosenv.2014.09.008, 2014.

Hammer, M. S., Martin, R. V., van Donkelaar, A., Buchard, V., Torres, O., Ridley, D. A., and Spurr, R. J. D.: Interpreting the ultraviolet aerosol index observed with the OMI satellite instrument to understand absorption by organic aerosols: implications for atmospheric oxidation and direct radiative effects, Atmos. Chem Phys., 16, 2507-2523, doi:10.5194/acp-16-2507-2016, 2016.

Hasekamp, O. P., Litvinov, P., and Butz, A.: Aerosol properties over the ocean from PARASOL multiangle photopolarimetric measurements, J. Geophys. Res., 116, D14204, doi:10.1029/2010JD015469, 2011.

Holben, B. N., Eck, T. F., Slutsker, I., Tanre, D., Buis, J. P., Setzer, A., Vermote, E., Reagan, J. A., Kaufman, Y., Nakajima, T., Lavenu, F., Jankowiak, I., and Smirnov, A.: AERONET - A federated instrument network and data archive for aerosol characterization, Remote Sens. Environ., 66, 1-16, 1998. 
Jethva, H. and Torres, O.: Satellite-based evidence of wavelengthdependent aerosol absorption in biomass burning smoke inferred from Ozone Monitoring Instrument, Atmos. Chem. Phys., 11, 10541-10551, doi:10.5194/acp-11-10541-2011, 2011.

Jethva, H., Torres, O., and Ahn, C.: Global Assessment of OMI Aerosol Single-scattering Albedo Using Ground-based AERONET Inversion, J. Geophys. Res.-Atmos., 119, 90209040, doi:10.1002/2014JD021672, 2014.

Kahn, R. A. and Gaitley, B. J.: An analysis of global aerosol type as retrieved by MISR, J. Geophys. Res. Atmos., 120, 4248-4281, doi:10.1002/2015JD023322, 2015.

Kalashnikova, O. V. and Kahn, R. A.: Mineral dust plume evolution over the Atlantic from MISR and MODIS aerosol retrievals, J. Geophys. Res., 113, D24204, doi:10.1029/2008JD010083, 2008.

Kaufman, Y. J.: Satellite sensing of aerosol absorption, J. Geophys. Res., 92, 4307-4317, doi:10.1029/JD092iD04p04307, 1987.

Kazadzis, S., Bais, A., Balis, D., Kouremeti, N., Zempila, M., Arola, A., Giannakaki, E., Amiridis, V., and Kazantzidis, A.: Spatial and temporal UV irradiance and aerosol variability within the area of an OMI satellite pixel, Atmos. Chem. Phys., 9, 4593-4601, doi:10.5194/acp-9-4593-2009, 2009.

Kim, D., Chin, M., Yu, H., Eck, T. F., Sinyuk, A., Smirnov, A., and Holben, B. N.: Dust optical properties over North Africa and Arabian Peninsula derived from the AERONET dataset, Atmos. Chem. Phys., 11, 10733-10741, doi:10.5194/acp-1110733-2011, 2011.

Kittaka, C., Winker, D. M., Vaughan, M. A., Omar, A., and Remer, L. A.: Intercomparison of column aerosol optical depths from CALIPSO and MODIS-Aqua, Atmos. Meas. Tech., 4, 131-141, doi:10.5194/amt-4-131-2011, 2011.

Kleidman, R., Smirnov, A., Levy, R. C., Mattoo, S., and Tanre, D.: Evaluation and wind speed dependence of MODIS aerosol retrievals over open ocean, IEEE T. Geosci. Remote, 99, 1-7, doi:10.1109/TGRS.2011.2162073, 2011.

Koch, D., Schulz, M., Kinne, S., McNaughton, C., Spackman, J. R., Balkanski, Y., Bauer, S., Berntsen, T., Bond, T. C., Boucher, O., Chin, M., Clarke, A., De Luca, N., Dentener, F., Diehl, T., Dubovik, O., Easter, R., Fahey, D. W., Feichter, J., Fillmore, D., Freitag, S., Ghan, S., Ginoux, P., Gong, S., Horowitz, L., Iversen, T., Kirkevåg, A., Klimont, Z., Kondo, Y., Krol, M., Liu, X., Miller, R., Montanaro, V., Moteki, N., Myhre, G., Penner, J. E., Perlwitz, J., Pitari, G., Reddy, S., Sahu, L., Sakamoto, H., Schuster, G., Schwarz, J. P., Seland, Ø., Stier, P., Takegawa, N., Takemura, T., Textor, C., van Aardenne, J. A., and Zhao, Y.: Evaluation of black carbon estimations in global aerosol models, Atmos. Chem. Phys., 9, 9001-9026, doi:10.5194/acp-9-9001-2009, 2009

Krotkov, N. A., Flittner, D. E., Krueger, A. J., Kostinski, A., Riley, C., Rose, W., and Torres, O.: Effect of particle nonsphericity on satellite monitoring of drifting volcanic ash clouds, J. Quant. Spectrosc. Ra., 63, 613-630, doi:10.1016/S00224073(99)00041-2, 1999.

Krotkov, N. A., Schoeberl, M. R., Morris, G. A., Carn, S., and Yang, K.: Dispersion and lifetime of the $\mathrm{SO}_{2}$ cloud from the August 2008 Kasatochi eruption, J. Geophys. Res., 15, D00L20, doi:10.1029/2010JD013984, 2010.

Lacagnina, C., Hasekamp, O. P., Bian, H., Curci, G., Myhre, G., van Noije, T., Schulz, M., Skeie, R. B., Takemura, T., and Zhang, K.: Aerosol single-scattering albedo over the global oceans: Com- paring PARASOL retrievals with AERONET, OMI, and AeroCom models estimates, J. Geophys. Res. Atmos., 120 , 9814 9836, doi:10.1002/2015JD023501, 2015.

Level-1 \& Atmosphere Archive and Distribution System (LAADS) Distributed Active Archive Center: Aqua/MODIS Atmosphere L2 Aerosol Product (MYD04), available at: 10.5067/MODIS/ MYD04_L2.006, last access: 7 July 2016.

Levelt, P. F., Hilsenrath, E., Leppelmeier, G. W., van den Ooord, G. H. J., Bhartia, P. K., Taminnen, J., de Haan, J. F., and Veefkind, J. P.: Science objectives of the Ozone Monitoring Instrument, IEEE Trans. Geosci. Remote S., 44, 1093-1101, 2006.

Levy, R. C., Remer, L. A., Tanre, D., Mattoo, S., and Kaufman, Y. J.: Algorithm for remote sensing of tropospheric aerosol over dark targets from MODIS: Collections 005 and 051: Revision 2, MODIS Algorithm Theoretical Basis Document, 2009.

Levy, R. C., Mattoo, S., Munchak, L. A., Remer, L. A., Sayer, A. M., Patadia, F., and Hsu, N. C.: The Collection 6 MODIS aerosol products over land and ocean, Atmos. Meas. Tech., 6, 29893034, doi:10.5194/amt-6-2989-2013, 2013.

Liu, Z., Winker, D. M., Omar, A. H., Vaughan, M., Trepte, C. R., Hu, Y., Hostetler, C. A., Sun, W., and Lin, B.: Effective lidar ratios of dense dust layers over North Africa derived from the CALIOP measurements, J. Quant. Spectrosc. Ra., 112, 204-213, doi:10.1016/j.jqsrt.2010.05.006, 2011.

Loeb, N. G. and Su, W.: Direct Aerosol Radiative Forcing Uncertainty Based on a Radiative Perturbation Analysis, J. Climate, 23, 5288-5293, doi:10.1175/2010JCLI3543.1, 2010.

Loveland, T. R., Reed, B. C., Brown, J. F., Ohlen, D. O., Zhu, Z., Yang, L., and Merchant, J. W.: Development of a global land cover characteristics database and IGBP DISCover from $1 \mathrm{~km}$ AVHRR data, Int. J. Remote Sens., 21, 1303-1330, 2000.

Marmer, E., Dentener, F., Aardenne, J. v., Cavalli, F., Vignati, E., Velchev, K., Hjorth, J., Boersma, F., Vinken, G., Mihalopoulos, N., and Raes, F.: What can we learn about ship emission inventories from measurements of air pollutants over the Mediterranean Sea?, Atmos. Chem. Phys., 9, 6815-6831, doi:10.5194/acp-96815-2009, 2009.

Martins, J. V., Tanre, D., Remer, L., Kaufman, Y., Mattoo, S., and Levy, R.: MODIS Cloud screening for remote sensing of aerosols over oceans using spatial variability, Geophys. Res. Lett., 29, 1619, doi:10.1029/2001GL013252, 2002.

Mishchenko, M. I., Travis, L. D., Kahn, R. A., and West, R. A.: Modeling phase functions for dustlike tropospheric aerosols using a mixture of randomly oriented polydisperse spheroids, J. Geophys. Res., 102, 16831-16847, doi:10.1029/96JD02110, 1997.

NASA Goddard Earth Sciences Data and Information Services Center: OMI data, available at: doi:10.5067/Aura/OMI/DATA3003, last access: 7 July 2016.

NASA Langley Research Center Atmospheric Science Data Center: CALIOP data, available at: https://eosweb.larc.nasa.gov/, last access: 7 July 2016.

Peers, F., Waquet, F., Cornet, C., Dubuisson, P., Ducos, F., Goloub, P., Szczap, F., Tanré, D., and Thieuleux, F.: Absorption of aerosols above clouds from POLDER/PARASOL measurements and estimation of their direct radiative effect, Atmos. Chem. Phys., 15, 4179-4196, doi:10.5194/acp-15-4179-2015, 2015.

Remer, L. A., Kaufman, Y. J., Tanré, D., Mattoo, S., Chu, D. A., Martins, J. V., Li, R.-R., Ichoku, C., Levy, R. C., Kleidman, R. G., 
Eck, T. F., Vermote, E., and Holben, B. N.: The MODIS aerosol algorithm, products and validation, J. Atmos. Sci., 62, 947-973, 2005.

Samset, B. H. and Myhre, G.: Vertical dependence of black carbon, sulphate and biomass burning aerosol radiative forcing, Geophys. Res. Lett., 38, L24802, doi:10.1029/2011GL049697, 2011.

Satheesh, S. K., Torres, O., Remer, L. A., Babu, S. S., Vinoj, V., Eck, T. F., Kleidman, R. G., and Holben, B. N.: Improved assessment of aerosol absorption using OMI-MODIS joint retrieval, J. Geophys. Res., 114, D05209, doi:10.1029/2008JD011024, 2009.

Schoeberl, M. R., Douglass, A. R., Hilsenrath, E., Bhartia, P. K., Beer, R., Waters, J. W., Gunson, M. R., Froidevaux, L., Gille, J. C., Barnett, J. J., Levelt, P. F., and DeCola, P.: Overview of the EOS aura mission, IEEE Trans. Geo. Rem. Sens., 44, 10661074, doi:10.1109/TGRS.2005.861950, 2006.

Shi, Y., Zhang, J., Reid, J. S., Holben, B., Hyer, E. J., and Curtis, C.: An analysis of the collection 5 MODIS over-ocean aerosol optical depth product for its implication in aerosol assimilation, Atmos. Chem. Phys., 11, 557-565, doi:10.5194/acp-11-557-2011, 2011.

Smirnov, A., Holben, B. N., Slutsker, I., Giles, D. M., McClain,C. R., Eck, T. F., Sakerin, S. M., Macke, A., Croot, P., Zibordi, G., Quinn, P. K., Sciare, J., Kinne, S., Harvey, M. J., Smyth, T. J., Piketh, S., Zielinski, T., Proshutinsky, A., Goes, J. I., Nelson, N. B., Larouche, P., Radionov, V. F., Goloub, P., Moorthy, K. K., Matarrese, R., Robertson, E. J., and Jourdin, F.: Maritime Aerosol Network as a component of Aerosol Robotic Network, J. Geophys. Res., 114, D06204, doi:10.1029/2008JD011257, 2009.

Toledano, C., Cachorro, V. E., Berjon, A., de Frutos, A. M., Sorribas, M., de la Morena, B. A., and Goloub, P.: Aerosol optical depth and Ångström exponent climatology at El Arenosillo AERONET site (Huelva, Spain), Q. J. Roy. Meteorol. Soc., 133, 795-807, doi:10.1002/qj.54, 2007.

Torres, O., Bhartia, P. K., Herman, J. R., and Ahmad, Z.: Derivation of aerosol properties from satellite measurements of backscattered ultraviolet radiation, Theoretical Basis, J. Geophys. Res., 103, 17099-17109, 1998.

Torres, O., Bhartia, P. K., Sinyuk, A., Welton, E. J., and Holben, B.: Total Ozone Mapping Spectrometer measurements of aerosol absorption from space: Comparison to SAFARI 2000 ground-based observations, J. Geophys. Res., 110, D10S18, doi:10.1029/2004JD004611, 2005.

Torres, O., Tanskanen, A., Veihelmann, B., Ahn, C., Braak, R., Bhartia, P., Veefkind, P., and Levelt, P.: Aerosols and surface UV products from Ozone Monitoring Instrument observations: An overview, J. Geophys. Res., 112, D24S47, doi:10.1029/2007JD008809, 2007.

Torres, O., Jethva, H., and Bhartia, P. K.: Retrieval of Aerosol Optical Depth above Clouds from OMI Observations: Sensitivity Analysis and Case Studies, J. Atm. Sci., 69, 1037-1053, doi:10.1175/JAS-D-11-0130.1, 2012.

Torres, O., Ahn, C., and Chen, Z.: Improvements to the OMI nearUV aerosol algorithm using A-train CALIOP and AIRS observations, Atmos. Meas. Tech., 6, 3257-3270, doi:10.5194/amt-63257-2013, 2013.

Veihelmann, B., Levelt, P. F., Stammes, P., and Veefkind, J. P.: Simulation study of the aerosol information content in OMI spectral reflectance measurements, Atmos. Chem. Phys., 7, 3115-3127, doi:10.5194/acp-7-3115-2007, 2007.
Wagner, R., Ajtai, T., Kandler, K., Lieke, K., Linke, C., Müller, T., Schnaiter, M., and Vragel, M.: Complex refractive indices of Saharan dust samples at visible and near UV wavelengths: a laboratory study, Atmos. Chem. Phys., 12, 2491-2512, doi:10.5194/acp-12-2491-2012, 2012.

Wang, J., Liu, X., Christopher, S. A., Reid, J. S., Reid, E., and Maring, H.: The effects of non-sphericity on geostationary satellite retrievals of dust aerosols, Geophys. Res. Lett., 30, 2293, doi:10.1029/2003GL018697, 24, 2003.

Wang, J., Park, S., Zeng, J., Ge, C., Yang, K., Carn, S., Krotkov, N., and Omar, A. H.: Modeling of 2008 Kasatochi volcanic sulfate direct radiative forcing: assimilation of $\mathrm{OMI} \mathrm{SO}_{2}$ plume height data and comparison with MODIS and CALIOP observations, Atmos. Chem. Phys., 13, 1895-1912, doi:10.5194/acp-13-18952013, 2013.

Wang, X., Heald, C. L., Ridley, D. A., Schwarz, J. P., Spackman, J. R., Perring, A. E., Coe, H., Liu, D., and Clarke, A. D.: Exploiting simultaneous observational constraints on mass and absorption to estimate the global direct radiative forcing of black carbon and brown carbon, Atmos. Chem. Phys., 14, 10989-11010, doi:10.5194/acp-14-10989-2014, 2014.

Wells, K. C., Martins, J. V., Remer, L. A., Kreidenweis, S. M., and Stephens, G. L.: Critical reflectance derived from MODIS: Application for the retrieval of aerosol absorption over desert regions, J. Geophys. Res.-Atmos., 117, D03202, doi:10.1029/2011JD016891, 2012.

Winker, D. M., Pelon, J., and McCormick, M. P.: The CALIPSO mission: Spaceborne lidar for observation of aerosols and clouds, Proc. SPIE, 4893, 1-11, 2003.

Zhang, J. and Reid, J. S.: A decadal regional and global trend analysis of the aerosol optical depth using a data-assimilation grade over-water MODIS and Level 2 MISR aerosol products, Atmos. Chem. Phys., 10, 10949-10963, doi:10.5194/acp-1010949-2010, 2010.

Zhang, W., Gu, X., Xu, H., Yu, T., and Zheng, F.: Assessment of OMI near-UV aerosol optical depth over Central and East Asia, J. Geophys. Res.-Atmos., 120, 382-398, doi:10.1002/2015JD024103, 2015.

Zhang, L., Henze, D. K., Grell, G. A., Carmichael, G. R., Bousserez, N., Zhang, Q., Torres, O., Ahn, C., Lu, Z., Cao, J., and Mao, Y.: Constraining black carbon aerosol over Asia using OMI aerosol absorption optical depth and the adjoint of GEOS-Chem, Atmos. Chem. Phys., 15, 10281-10308, doi:10.5194/acp-1510281-2015, 2015.

Zhao, C. and Wang, Y.: Assimilated inversion of NOx emissions over east Asia using $\mathrm{OMI} \mathrm{NO}_{2}$ column measurements, Geophys. Res. Lett., 36, L06805, doi:10.1029/2008GL037123, 2009.

Zhu, L., Martins, J. V., and Remer, L. A.: Biomass burning aerosol absorption measurements with MODIS using the critical reflectance method, J. Geophys. Res., 116, D07202, doi:10.1029/2010JD015187, 2011.

Ziemke, J. R., Olsen, M. A., Witte, J. C., Douglass, A. R., Strahan, S. E., Wargan, K., Liu, X., Schoeberl, M. R., Yang, K., Kaplan, T. B., Pawson, S., Duncan, B. N., Newman, P. A., Bhartia, P. K., and Heney, M. K.: Assessment and applications of NASA ozone data products derived from Aura OMI/MLS satellite measurements in context of the GMI Chemical Transport Model, J. Geophy. Res. Atmos., 119, 5671-5699, doi:10.1002/2013JD020914, 2014. 